\title{
AVALIAÇÃO DAS PERDAS DE VALOR NUTRITIVO DURANTE O PROCESSO DE FENAÇÃO DA CULTURA DA ALFAFA EM TRÊS PROPRIEDADES NO NORTE DO PARANÁ.
}

MARIZA FORDELONE ROSA CRUZ

Médica Veterinária

Orientador: Prof. Dr. WILSON ROBERTO SOARES MATTOS

Dissertação apresentada à Escola Superior de Agricultura "Luiz de Queiroz", Universidade de São Paulo, para obtenção do título de Mestre em Agronomia, Área de Concentração: Ciência Animal e Pastagens.

P I R A C I C A B A

Estado de São Paulo - Brasil

Fevereiro- 1997 


\section{Dados Internacionais de Catalogação na Publicação (CIP) DIVISÃO DE BIBLIOTECA E DOCUMENTAÇÃO - Campus "Luiz de Oueiroz"/USP}

Cruz, Mariza Fordelone Rosa

Avaliação das perdas de valor nutritivo durante o processo de fenação da cultura da alfafa em três propriedades no norte do Paraná / Mariza Fordelone Rosa Cruz. - Piracicaba, 1997.

$71 \mathrm{p}$.

Dissertaçāo (mestrado) - Escola Superior de Agricultura Luiz de Queiroz, 1997. Bibliografia.

1. Alfafa 2. Fenação 3. Perda de nutriente I. Título

CDD 633.31

636.08552 


\section{AVALIAÇÃO DAS PERDAS DE VALOR NUTRITIVO DURANTE O PROCESSO DE FENAÇÃO DA CULTURA DA ALFAFA EM TRÊS PROPRIEDADES NO NORTE DO PARANÁ.}

\section{MARIZA FORDELONE ROSA CRUZ}

Aprovada em: 30.06 .1997

Comissão Julgadora:

Prof. Dr. Wilson Roberto Soares Mattos

ESALQ/USP

Prof. Dr. Sila Carneiro da Silva

ESALQ/USP

Prof $^{a} \mathrm{Dr}^{\mathrm{a}}$ Dorinha Miriam Silber Schimdt Vitti

CENA/USP

Prof. Dr. Wilson Roberto Soares Mattos Orientador 


\section{DEDICATÓRIA}

AOS MEUS PAIS, IGNÊS E MUSSOLINO, AO MEU IRMÃO PAULO FERNANDO, AOS MEUS AVÓS MARIA E EVARISTO, À MINHA TIA LOURDES, POR TODO APOIO, DEDICO.

AOS MEUS FILHOS CAROLINA, MARIANA E GABRIEL AO MEU ESPÔSO, ROBERTO POR TODA COMPREENSÃO E CARINHO, OFEREÇO. 


\section{AGRADECIMENTOS}

Ao Prof. Wilson Roberto Soares Mattos pela orientação ao trabalho.

Aos Professores do Departamento de Zootecnia da ESALQ-USP pelos ensinamentos

Ao Prof. Moacyr Corsi pelas sugestões para o planejamento do experimento.

Ao Prof. Max Lázaro Vieira Bose pela amizade, paciência e colaboração.

Ao Departamento de Física e Metereologia da Esalq, em especial ao Professor Nilson Augusto Villa Nova por toda orientação e apoio.

Aos professores e amigos do CENA, em especial ao Dr. Adibe Luiz Abdalla.

Aos irmãos André, Isidoro e Silvio Maluta, e Arnaldo Roltzmann Jr. pela gentileza de ceder as áreas de alfafa para coleta.

Ao amigo Henning Mario von Rautenfeld pela colaboração no preparo das amostras para análise.

Ao amigo Renzo Goretta Hugo, pela colaboração nas amostragens do material.

Ao amigo Carlos César Alves do laboratório de bromatologia da Esalq.

À Fundação Faculdade de Agronomia Luiz Meneghel pela utilização do laboratório e material bibliográfico.

Aos funcionários da biblioteca da ESALQ, em especial à Silvana, Fátima, Kátia e Eliana que sempre colaboraram nas revisões bibliográficas.

Aos funcionários do Ciagri, em especial à Marilza por sua simpatia.

Aos professores Cristina S. Nogueira, José Eduardo Corrente e Carlos Tadeu dos Santos Dias do Departamento de Matemática e Estatística/ ESALQ-USP, Professor Hilton Tadeu Zarate do Couto do Departamento de Ciências Florestais/ ESALQ-USP, e aos pesquisadores José Erivaldo Pereira da Embrapa de Londrina e Marcelo Corrêa Alves do CIAGRI/ESALQ-USP, pela contribuição no planejamento experimental, e processamento e análise estatística dos dados.

Ao CNPQ pelos recursos financeiros.

Às amigas Valéria e Veridiana que deram a maior força na reta final.

A todos os amigos que direta ou indiretamente participaram deste trabalho. 


\section{SUMÁRIO}

Página

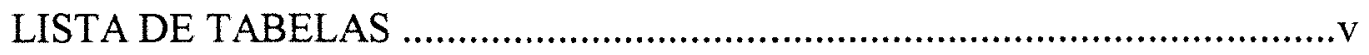

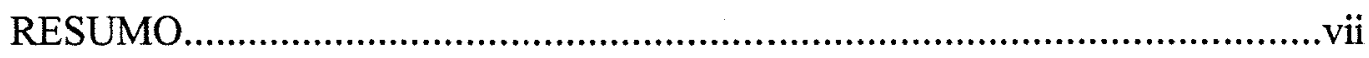

SUMMARY

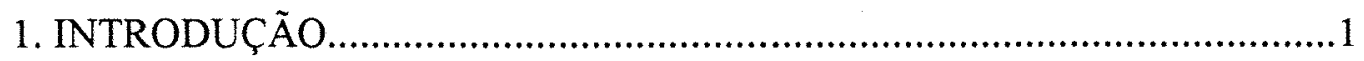

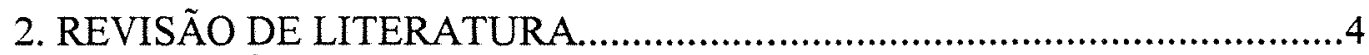

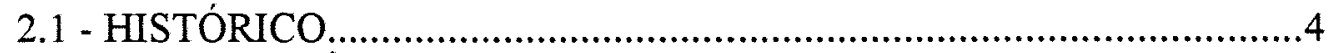

2.2 - CARACTERÍSTICAS DA PLANTA …….........................................

2.3 - CLIMA

2.4 - SOLO

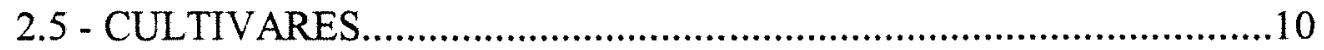

2.6 - ESTABELECIMENTO DA CULTURA..........................................10

2.7 - CONSERVAÇÃO DA FORRAGEM ATRAVÉS DA FENAÇÃO......12

2.7.1.- PERDAS DURANTE A SECAGEM DO FENO.............................13

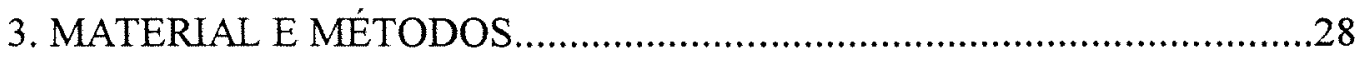

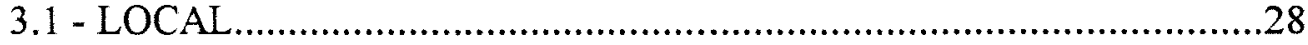

3.2 - MATERIAL UTILIZADO ..........................................................29

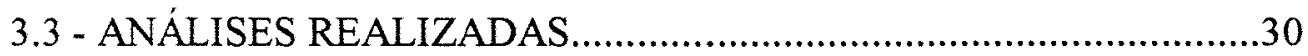

3.4 - DELINEAMENTO EXPERIMENT AL_..........................................32

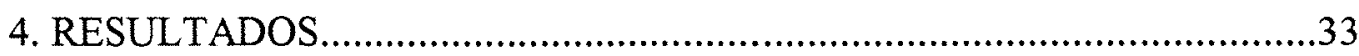

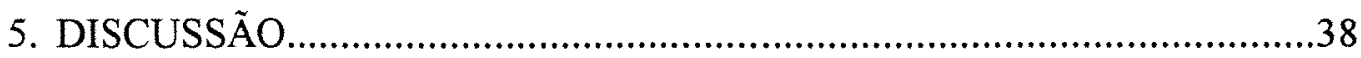

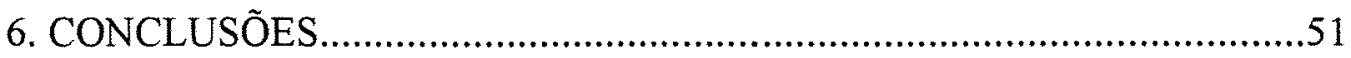

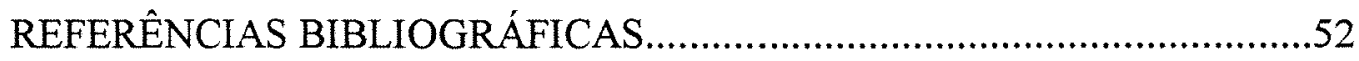

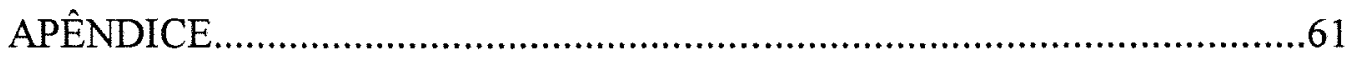


LISTA DE TABELAS

PÁGINA

TABELA 1 - Produção de alfafa forrageira no Brasil e contribuição relativa dos principais estados produtores......................................................6

TABELA 2 - Princípios nutritivos da alfafa (Medicago sativa L) em vários estágios de desenvolvimento...................................................................14

TABELA 3 - Estádio vegetativo da planta em cada corte.....................................28

TABELA 4 - Datas de corte da alfafa e coleta nas 3 propriedades estudadas...... 29

TABELA 5- Princípios nutritivos brutos- Propriedade 1 /período 1 .......................33

TABELA 6- Princípios nutritivos brutos- Propriedade 1 /período 2......................33

TABELA 7- Princípios nutritivos brutos- Propriedade 2 /período 1 .........................34

TABELA 8- Princípios nutritivos brutos- Propriedade 2 /período 2.......................34

TABELA 9- Princípios nutritivos brutos- Propriedade 3 /período 1........................35

TABELA 10- Princípios nutritivos brutos- Propriedade 3 /período 2.....................35

TABELA 11- Perdas de proteína bruta da alfafa (\%)- Propriedade 1.....................36

TABELA 12- Perdas de proteína bruta da alfafa (\%)- Propriedade 2...................36

TABELA 13- Perdas de proteina bruta da alfafa (\%)- Propriedade 3....................37

TABELA 14- Coeficientes de correlação entre os princípios nutritivos brutos propriedade $1 /$ período 1 .......................................................62

TABELA 15- Coeficientes de correlação entre os princípios nutritivos brutos propriedade $1 /$ período 2 ...............................................................62

TABELA 16- Coeficientes de correlação entre os princípios nutritivos brutos propriedade $2 /$ período 1

TABELA 17- Coeficientes de correlação entre os princípios nutritivos brutos propriedade 2 / período 2 
TABELA 18- Coeficientes de correlação entre os princípios nutritivos brutos propriedade 3 / período 1 .64

TABELA 19- Coeficientes de correlação entre os princípios nutritivos brutos propriedade 3 / período 2 .64

TABELA 20- Análise de Variância- Propriedade 1...............................................65

TABELA 21- Análise de Variância- Propriedade 2................................................65

TABELA 22- Análise de Variância- Propriedade 3..............................................66

TABELA 23 - Dados climatológicos da propriedade 1/ período 1 1........................67

TABELA 24 - Dados climatológicos da propriedade 1/ período 2........................67

TABELA 25 - Atividade da água no ar em função da temperatura e umidade relativa do ar - propriedade 1 .......................................68

TABELA 26 - Aspectos climatológicos da propriedade 2 - período 1 ................ 68

TABELA 27 - Aspectos climatológicos da propriedade 2 - período 2 ...............69

TABELA 28 - Atividade da água no ar em função da temperatura e umidade relativa do ar - propriedade 2 .69

TABELA 29 - Aspectos climatológicos da propriedade 3 - período 1 ……..........70

TABELA 30 - Aspectos climatológicos da propriedade 3 - periodo 2 .................70

TABELA 31 - Atividade da água no ar em função da temperatura e

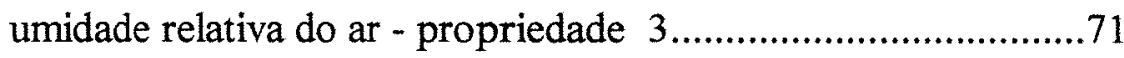




\title{
AVALIAÇÃO DAS PERDAS DE VALOR NUTRITIVO DURANTE O PROCESSO DE FENAÇÃO DA CULTURA DA ALFAFA EM TRÊS PROPRIEDADES NO NORTE DO PARANÁ.
}

\author{
Autor: Mariza Fordelone Rosa Cruz \\ Orientador: Prof. Dr. Wilson R. Soares Mattos
}

\section{RESUMO}

O experimento foi conduzido na região norte do Paraná, cidade de Itambaracá. $\mathrm{O}$ clima é tropical de altitude, temperatura média entre $17-22^{\circ} \mathrm{C}$, pluviosidade de $1500 \mathrm{~mm}$ anuais. $\mathrm{O}$ objetivo do trabalho foi avaliar as perdas em valor nutritivo durante o processo de produção de feno de alfafa através das modificações ocorridas nos valores de matéria seca (MS), relação haste /folha (RHF), proteína bruta $(\mathrm{PB})$, fibra bruta $(\mathrm{FB})$, extrato etéreo (EE), matéria mineral (MM), extrativo não nitrogenado (ENN) e nutrientes digestiveis totais (NDT). Foram selecionadas 3 propriedades com características fisicas semelhantes e mesmo manejo da cultura, onde foram feitas colheitas de amostras em 2 cortes de alfafa, (períodos 1 e 2- junho e agosto ), e cinco fases distintas (1-5, sendo elas: verde, logo após corte, 1 dia de secagem a campo, 2 dias de secagem a campo, feno ). Foram feitas análises bromatológicas em todas as fases para verificar a perda ocorrida e avaliar o processo de fenação.

Durante o período os dados climatológicos: temperatura- ${ }^{\circ} \mathrm{C}$, umidade relativa do ar-(URA \%), ventos - $\mathrm{km} /$ acumulados/dia, radiação calorias $/ \mathrm{cm} 2 /$ dia, insolação-horas/sol/dia, foram obtidos no posto metereológico da Fundação Faculdade de Agronomia Luiz Meneghel na cidade de Bandeirantes a cerca de $12 \mathrm{Km}$ das áreas amostradas.

O delineamento experimental utilizado foi o inteiramente casualizado, com 4 repetições. Foi avaliado o fator fases em cada propriedade e período. 
Os Valores de MS, RHF e FB aumentaram $(p<0,05)$, enquanto que os valores de $P B$, e NDT diminuiram $(p<0,05)$, e os valores de $E E$, ENN e MM não sofreram alterações significativas no decorrer do processo de secagem (fases 1 a 5 ).

Pode-se inferir que a radiação solar e velocidade do vento, provavelmente influenciaram sobre $o$ processo de secagem natural do feno. $O$ fator que aparentemente mais influenciou foi a umidade relativa do ar (URA). Quanto maior a URA, menor o poder secativo do ar, tornando mais dificil a secagem da forragem.

A relação haste/folha foi um bom parâmetro para acompanhamento de perdas de folhas. Houve o aumento gradativo desta relação durante o processo de secagem, ou seja, ocorreu a perda de folhas e, em contrapartida, o aumento das hastes.

As perdas ocorreram a partir da fase 2, e foram mais intensas nas fases 3 e 4 , um e dois dias de campo, respectivamente, em especial na fase 4, pois a planta permanecendo mais que 1 dia a campo apresentou maior perda global. 


\title{
EVALUATION OF A SYSTEM OF THE ALFALFA HAY PRODUCTION (Medicago sativa $L$.) IN THE NORTHERN REGION OF PARANÁ STATE.
}

\author{
Author: Mariza Fordelone Rosa Cruz \\ Adviser: Prof. Dr. Wilson R. Soares Mattos
}

\section{SUMMARY}

This study was carried out in the Northern Region of Paraná state, in Itambaracá - Brasil. Three farms were selected based on similar characteristics, alfalfa variety and management practices.

The objectives of the study were to evaluate the system of production of the alfalfa hay, and measure the changes in MS \% (dry matter), RHF (steam leaf ratio), $\mathrm{PB} \%$ (crude protein), FB \% (crude fiber), EE \% (ether extract), MM \% (ash), ENN $\%$ (nitrogen free extract), and NDT \% ( total digestible nutrients ), during the hay making process.

The alfalfa samples were collected in two cuts (periods 1 and 2 ), and in five differents phases: green vegetative (about 50 days up growth)(1), soon after cut (2). wilted-one day (3), wilted-two days(4), and hay (5).

The experimental design was a completely randomized one with four replications, where the factor phases was evalued in wich propriety and period. The statistical analysis was made using the Statistical Analistics System (SAS) software.

It was concluded that MS, FB, ENN and RHF increased $(p<0,05)$ and the $\mathrm{PB}, \mathrm{EE}, \mathrm{MM}$ and NDT decreased $(\mathrm{p}<0.05)$ during the haymaking process. 
Metheorological parameters were observed and probably relative humidity, global solar radiation and wind velocity, influenced in the natural hay making process, and apparently the relative humidity was the most important one.

The steam/leaf ratio was a good parameter to indicate leaf losses, and was related with decrease of crude protein.

The losses ocurred at the onset of phase 2, and they were more intense in phases 3 and 4 , specially phase 4 . 


\section{AVALIAÇÃO DAS PERDAS DE VALOR NUTRITIVO DURANTE O PROCESSO DE FENAÇÃO DA CULTURA DA ALFAFA EM TRÊS PROPRIEDADES NO NORTE DO PARANÁ.}

\section{INTRODUÇÃO:}

A alfafa (Medicago sativa $L$.) é uma das forragens mais importantes nos EUA e Canadá (HANSON et al, 1972). Também se destaca no Brasil, principalmente na produção de feno destinada a alimentação de equinos em fazendas de criação, haras especializados na criação de animais utilizados na prática de corridas, hipismo e criações exóticas. Alguns produtores de leite interessam-se pelo seu cultivo para utilização para vacas leiteiras de alta produção. Devido à sua alta qualidade como forrageira e o alto valor comercial do feno, presta-se para a alimentação de animais de alta produtividade ou valor comercial.

A alfafa chegou ao Brasil via Rio Grande do Sul, através do Uruguai e Argentina. É uma planta forrageira de caráter perene da família das leguminosas (Leguminosae), subfamilia Papilonoidea. Seu cultivo é originário do Sudoeste Asiático; alguns trabalhos mencionam como a sua origem o Irã , e que sua presença ocorria desde a China até a Espanha. Aclimatou-se em várias localidades como: África do Sul, Austrália, Nova Zelândia, Europa Ocidental, América do Norte e América do Sul (BOLTON et al, 1972).

O clima das regiões produtoras de alfafa foi caracterizado como continental, com invernos frios, primavera longa, verões quentes e secos e solos com pH próximo à neutralidade $(\mathrm{pH}=7,0)$, com elevado teor de cálcio na superfície e subsolo ( $\mathrm{SÁ}$ e PETRERE, 1991).

A alfafa é rica em proteínas, cálcio, fósforo e vitaminas A, B1, B2, C, E e K e produz uma forragem tenra e palatável (NUERNBERG, 1986). 
A produtividade média da alfafa varia de 9,8 a 22,0 ton./MS.ha.ano, de acordo com a incidência de pragas e doenças, fertilização, irrigação, estação do ano, fatores edáficos e climáticos, manejo da cultura e variedade entre outros. A obtenção de altas produtividades de alfafa remove do solo elevadas quantidades de nutrientes se comparada com as culturas produtoras de grãos (SÁ \& PETRERE, 1991).

A alfafa crioula apresenta rápida recuperação após os cortes, boa distribuição estacional e grande persistência. Tem-se observado que $70 \%$ da produção de matéria seca está concentrada no final da primavera, verão e fins de outono, e $30 \%$ no período frio (NUERNBERG, 1986).

Nas regiões tropicais e subtropicais as estações do ano não são bem definidas como nas regiões temperadas, e as características físicas e químicas dos solos nessas regiões são bem diferentes das regiões de origem da alfafa, que é uma cultura exigente em fertilidade, o que implica em alterar as propriedades físicas e químicas dos solos de regiões tropicais (SÁ \& PETRERE, 1991).

O estabelecimento da cultura em diversas situações de clima e solo está relacionada com o desenvolvimento do sistema radicular profundo (JUNG \& LARSON, 1972). Estes pesquisadores mostraram a grande importância do desenvolvimento do sistema radicular nos primeiros 40 dias. Durante os 10 dias após a germinação, 0 crescimento das raizes foi 10 vezes maior que o do caule, e nesta fase ocorreu a infecção e proliferação do Rhizobium meliloti, microrganismo responsável pela formação dos nódulos responsáveis pela fixação do nitrogênio. Nesta fase a baixa disponibilidade de água no solo afetaria seriamente o processo de estabelecimento do Rhizobium nas raízes.

O manejo inadequado do solo, proporcionando a sua compactação, pode inibir o crescimento inicial ou favorecer a bifurcação da raiz pivotante, induzindo maior consumo das reservas e formando raizes finas e superficiais (SÁ \& PETRERE, 1991). 
Apesar de ser uma cultura exigente, a alfafa tem se mostrado uma forrageira superior a outras leguminosas, em vários aspectos, incluindo a qualidade, produtividade e adaptabilidade a clima e solo, além do hábito ereto de crescimento, que possibilita a colheita para feno, silagem, forragem verde, e também o pastejo (NUERNBERG, 1986).

Tem a característica de tolerar melhor a seca que outras leguminosas, o que leva a uma melhor distribuição sazonal da produção. É uma fonte excelente de proteína de alta qualidade para animais, além de ser praticamente independente do nitrogênio do solo. Sua ingestão voluntária é em geral maior que a de gramíneas com a mesma digestibilidade, além da proteína ser de alta qualidade para ruminantes (KEPLIN \& SANTOS, 1991).

Tendo em vista o valor comercial do feno de alfafa, a maior tendência de sua comercialização é através de cortes a intervalos periódicos, em geral a cada 35 dias, para secagem e elaboração de fardos de feno. A fenação pode ser uma forma de conservação. Em casos de manejo inadequado durante as práticas usadas para a conservação da forrageira, a qualidade do produto final fica prejudicada, devido principalmente à perda de folhas, que constituem a parte da planta de maior digestibilidade (KEPLIN \& SANTOS, 1991)

A qualidade do feno de alfafa na região estudada tem sido considerada ruim, apresentando a média da porcentagem de PB do feno abaixo de $15 \%$, e produtividade média de 4 a 8 ton. MS/ha.ano. Estes valores são baixos quando comparados com as boas regiões produtoras de feno de alfafa, nas quais a média de produção gira em torno de 8,3 a 15,3 ton. MS/ha.ano (NUERNBERG, 1986).

Portanto, o objetivo deste trabalho foi avaliar o processo de fenação verificando-se em quais fases do processo ocorrem as maiores perdas de valor nutritivo e, ainda, se possível, quantificá-las buscando-se uma forma de minimizá-las para resultar um produto final de melhor qualidade. 


\section{Revisão de Literatura}

\subsection{Histórico:}

A alfafa tem uma longa e rica história, sendo reconhecida como a mais antiga planta utilizada para forragem. Alguns pesquisadores concordam que ela é originária da Ásia Menor, Transcaucásia, Irã e Turkmenistan (BOLTON et al, 1972). Nestas áreas ocorrem invernos frios e verões quentes, secos e curtos, além de primavera tardia. Os solos são bem drenados, $\mathrm{pH}$ neutro, com alto teor de óxido de cálcio. BOLTON et al, (1972) concluíram dos seus estudos sobre alfafa, que há dois diferentes centros de origem: o primeiro centro de origem é nas regiões montanhosas da Transcaucásia, que originaram as modernas alfafas da Europa: Ásia Menor e áreas adjacentes do noroeste do Irã.

O segundo centro é a Asia Central, onde o clima é caracterizado por baixa umidade, verões quentes, secos e invernos moderadamente frios, onde já era praticada a irrigação. $\mathrm{O}$ desenvolvimento das alfafas desta região, ocorreu devido à maior resistência das folhas a doenças, insetos, nematóides do caule, outros patógenos das raízes e afideos. Portanto não é acidental que esta região tenha sido uma fonte de germoplasma para outras regiões.

A alfafa é uma das forragens que foi "domesticada" com mais sucesso, provavelmente devido ao seu sistema radicular e a evolução da relação simbiótica entre as raízes e o Rhizobium, que propiciaram uma fonte de nitrogênio disponivel para a planta (JACQUES, 1988). O sistema radicular profundo da raiz central e as raizes axiais tornam possível utilizar a umidade disponivel do solo a profundidades que atingem a 6 metros, ou mais, propiciando uma vantagem para escapar de secas prolongadas. Também possui a habilidade de um período de latência em secas prolongadas e invernos rigorosos, e volta a crescer quando as condições estiverem favoráveis. Seu sistema de raízes, constituído de rizomas e raiz central pivotante, promove proteção em invernos rigorosos (BOLTON, 1962). 
Durante o período do império romano (27 A.C.- 395 D.C.), os romanos estabeleceram a cultura da alfafa nas províncias conquistadas. Nos primeiros 100 anos depois de Cristo, COLUMELLA (1941) plantou alfafa na Andaluzia e sul da Espanha e ao mesmo tempo a cultura começou a se generalizar na região do lago Lucerne na Suíça central. Nesta mesma época foi introduzida no sul da França. foi citada por BOLTON et al (1972), a possibilidade da introdução da alfafa na Espanha através das invasões mouras. A preferência da utilização da palavra arábica alfalfa ao invés das palavras romanas medica ou lucerne, fazem crer nesta rota alternativa.

A queda do império romano marcou o desaparecimento virtual da cultura da alfafa na Europa. Quase nenhuma menção foi feita na "idade negra" (400- 1400 D.C.). Alguns autores italianos do periodo da renascença descreveram que a alfafa praticamente desapareceu. Com as invasões bárbaras no ano de 500 D.C., a própria agricultura teve severas quedas nesse periodo (BOLTON et al, 1972).

Porém em 1600 D.C. a alfafa foi reintroduzida na Europa, da Itália até a Espanha, e se espalhou rapidamente neste país. KLINKOWISKY, 1933 (citado por BOLTON et al, 1972) descreveu que a alfafa foi introduzida na França em 1550, na Bélgica e Holanda em 1565, na Inglaterra em 1650, na Alemanha e na Áustria em torno de 1750, na Suécia em 1770, na Rússia em torno de 1800, e, a partir de 1800, foi levada da Europa para o "Novo Mundo" (Américas), Austrália e Nova Zelândia. O advento da alfafa nas Américas levou a uma era de rápida expansão, e a cultura passou então a ser conhecida como a "Rainha das Forrageiras" (BOLTON et al, 1972).

Hoje a alfafa encontra-se disseminada em várias partes do mundo, inclusive na América do Sul, onde se destaca a Argentina apresentando uma área cultivada de aproximadamente sete milhões de hectares (SAIBRO, 1984).

A entrada da cultura no Brasil, provavelmente se deu através da Argentina e do Uruguai, passando para o Rio Grande do Sul, de onde difundiu-se para os Estados 
vizinhos, Santa Catarina e Paraná. Existem evidências de que imigrantes alemães e italianos tenham trazido sementes da Europa (NUERNBERG, 1986).

Os dados atualizados sobre a área utilizada e produção nos Estados são limitados. Um dos últimos levantamentos realizados publicado pela Fundação Instituto Brasileiro de Geografia e Estatística (Censo Agropecuário, 1984) relativo à produção do ano de 1980, indicou que a maior concentração em área e em produção encontra-se no sul do Brasil (Tabela 1). Verifica-se que o Rio Grande do Sul e o Paraná respondiam, na época do levantamento, por $\mathbf{8 3 . 8 6 \%}$ da produção nacional. Dados mais recentes, do anuário Estatístico do Brasil (1989), estimaram um aumento significativo na produção do estado de Santa Catarina, praticamente igualando-se ao Paraná, no ano de 1987.

Tabela 1- Produção de alfafa forrageira no Brasil (toneladas) e contribuição relativa dos principais estados produtores nos anos de 1980 e 1987 .

\begin{tabular}{|c|c|c|c|c|}
\hline & \multicolumn{2}{|c|}{1980} & \multicolumn{2}{c|}{1987} \\
\hline & Produção & Contribuição & Produção & Contribuição \\
\hline & Ton. & $\%$ & Ton. & $\%$ \\
\hline R Grande do Sul & 22.468 & 52,52 & 56.539 & 67,66 \\
\hline Paraná & 13.408 & 31,34 & 12.876 & 15,41 \\
\hline Santa Catarina & 2.767 & 6,47 & 12.799 & 14,326 \\
\hline São Paulo & 2.568 & 6,00 & 1.330 & 1,6 \\
\hline Minas Gerais & 874 & 2,04 & 8 & 0,01 \\
\hline Ceará & 347 & 0,81 & - & - \\
\hline Rio de Janeiro & 319 & 0,74 & - & - \\
\hline Outros & 26 & 0,08 & & - \\
\hline Total & 42.777 & 100 & 83.552 & 100 \\
\hline
\end{tabular}

Fonte: Rando, 1992. 


\section{2 - CARACTERÍSTICAS DA PLANTA}

A alfafa é uma cultura perene de crescimento dito estival, pertencente à família Leguminosae subfamília Papilonoidea. Possui sistema radicular tipo pivotante que pode atingir de 2 a $5 \mathrm{~m}$ de profundidade, e em alguns casos, pode chegar até $20 \mathrm{~m}$ segundo citações feitas por NUERNBERG et al (1990). Este crescimento determina a capacidade da planta extrair água das camadas mais profundas do solo, apresentando, portanto, resistência à seca (HONDA \& HONDA, 1990). Entre 30 e $60 \mathrm{~cm}$ da superficie a raiz apresenta intensa ramificação secundária, responsável pelo suprimento de nutrientes (HANSON, 1972).

RUSSEL (1980) citado por SÁ \& PETRERE (1991), fez uma revisão bibliográfica e mostrou que o sistema radicular desenvolve-se primeiramente em função da umidade, diretamente relacionada com hidrólise, reações bioquímicas e ativação do tecido meristemático, secundariamente depende da temperatura, que regula a velocidade de crescimento, das reações bioquímicas e fisiológicas, em terceiro lugar, da aeração, que regula a atividade respiratória através do fornecimento do oxigênio, e em quarto lugar, dos nutrientes em quantidade e qualidade adequada aos processos vitais da planta. HONDA \& HONDA (1990) descreveram que a planta sintetiza grande quantidade de carboidratos, que são acumulados na forma de açucares, na parte inferior dos caules que se engrossam formando rizomas.

\section{3 - CLIMA}

O clima encontrado nas regiões produtoras de alfafa foi classificado como continental com invernos frios, primavera longa e verões quentes e secos, mas é cultivada mundialmente, adaptando-se a vários tipos de clima. Sua produtividade alterase em função da variação intensa de temperatura e fotoperiodismo (HONDA \& HONDA, 1990). 
A alfafa é cultivada em regiões de baixas temperaturas, ampla variação no fotoperíodo, intensidade luminosa baixa, e até em climas subtropicais. Desenvolve-se bem em climas litorâneos com invernos frios e verões quentes e secos. Em geral altas temperaturas e alta intensidade luminosa promovem um grande desenvolvimento vegetativo e reprodutivo . A faixa ótima de temperatura para a fotossíntese máxima está entre 10 e $25^{\circ} \mathrm{C}$. A semente pode iniciar germinação entre 2 e $5^{\circ} \mathrm{C}$, desde que a umidade do solo não seja limitante (NUERNBERG et al, 1990).

A redução da germinação está associada com a redução na taxa e quantidade de água disponível para a semente. HANSON (1988) verificou que a germinação pode também ser reduzida por efeitos tóxicos de sais como $\mathrm{NaCl}, \mathrm{MgCl} 2, \mathrm{Na} 2 \mathrm{SO} 4$ ou $\mathrm{Na} 2 \mathrm{CO}$; combinações destes sais parecem ser menos tóxicas que os sais isoladamente.

A alfafa tem sua produção reduzida no inverno e em casos de geada pode sofrer drástica redução de crescimento, mas não chega a morrer, e esta pode ser até benéfica, eliminando plantas daninhas. Em invernos amenos continua a crescer porém em taxas menores, havendo menor incidência de flores (maio a setembro). A maior ou menor tolerância à baixas temperaturas ou fotoperiodos é conhecida como latência hibernal. Estas características relacionam-se com a fisiologia da planta como expansão foliar, alongamento de entrenós, acúmulo de substâncias de reserva nas raízes, que permitem à planta emitir seus afilhos em condições de ambiente mais favoráveis (NUERNBERG et al, 1990).

HONDA \& HONDA (1990) verificaram que no verão quando o clima é quente, a cultura passa a ter menor produtividade, pois a planta é mais susceptivel ao calor, e há maior incidência de pragas e doenças, tanto foliculares como radiculares. No Brasil verifica-se melhor produtividade na primavera e no outono, quando o clima é mais ameno com ventos e brisas suaves. No outono e inverno, devido às temperaturas mais amenas e fotoperiodismos mais curtos, o metabolismo da planta é menor, e os intervalos de corte mais prolongados. Nesta época, devido à menor incidência de flores, define-se o corte através das brotações basilares, que não podem ultrapassar a altura de corte. $\mathrm{Na}$ 
primavera e verão, os intervalos de corte são menores, e o momento do corte pode ser definido quando 10 a $20 \%$ do alfafal estiver em plena floração.

A alfafa é considerada como uma planta tolerante à seca devido ao aprofundamento das raízes, quando as condições de solo assim o permitem. Para produzir $1 \mathrm{~kg}$ de matéria seca é necessário que a planta absorva de 700 a $800 \mathrm{~kg}$ de água, enquanto que para outros cereais de inverno, como aveia, cevada e trigo, e de verão, como sorgo e milho, o volume de água necessário é de $500-600$ e $300-350 \mathrm{~kg}$ respectivamente. Se houver uma boa distribuição de chuvas durante o ano ( 900 a 1400 $\mathrm{mm}$ ), a necessidade de água pode ser suprida, e no caso de falta de chuvas pode-se suplementar com irrigação. A alfafa não tolera excesso de água, pois reduz a aeração no solo e pode levar à morte das plantas, reduzindo a produção (NUERNBERG et al, 1990).

\section{4 - SOLO}

O solo é de fundamental importância em relação ao estabelecimento da cultura, produtividade e longevidade, uma vez que as condições climáticas não são limitantes. $\mathrm{O}$ solo poderá ser alterado em suas propriedades químicas e físicas, através de tratos culturais como calagem e adubação química e orgânica, de acordo com a fertilidade própria do solo, que deve ser determinada em princípio pela análise de solo (KEPLIN \& SANTOS, 1991). O preparo do solo através de arações e gradagens ou subsolagens de acordo com a necessidade, e para a incorporação de adubos e/ou corretivos também é importante (HONDA \& HONDA, 1990).

Os solos com boa profundidade e permeabilidade, com lençol freático a mais de $2 \mathrm{~m}$ de profundidade, são aptos para o desenvolvimento da cultura, especialmente devido ao sistema radicular fusiforme e penetrante da raiz da alfafa, NUERNBERG et al (1990). A alfafa adapta-se mais em solos areno-argilosos. O fator mais limitante para o crescimento é a acidez do solo e também a toxidez do alumínio e manganês, e baixa 
disponibilidade de fósforo. A faixa ótima de $\mathrm{pH}$ para a alfafa é de 6- 7,5. A prática de calagem, visando a elevação do $\mathrm{pH}$, suprimento de $\mathrm{Ca}$ e $\mathrm{Mg}$ e eliminação de $\mathrm{Al}$ e $\mathrm{Mg}$ trocáveis associados à adubação fosfatada e potássica, promove condições para uma nodulação eficiente e obtenção de altos rendimentos de produção (HONDA \& HONDA, 1990).

Na região norte do Paraná, onde se concentra a maior área de cultivo de alfafa, o solo é argiloso, porém bastante fértil. Por esse motivo a cultura aí se implantou e obteve sucesso.

\section{5 - CULTIVARES:}

No Rio Grande do Sul e em Santa Catarina o processo de seleção determinou o surgimento de uma cultivar amplamente adaptada conhecida como "crioula". Ela recupera-se rapidamente após os cortes, apresenta bons rendimentos de matéria seca, boa distribuição estacional da produção e grande persistência. Em experimentos conduzidos na estação experimental de Lajes/SC, onde foram testados níveis de calcário e fósforo, obteve-se produções médias de 7 a 10 ton. de matéria seca/ ha.ano. Em trabalhos de competição de alfafa realizados no Rio Grande do Sul a cultivar crioula foi a mais produtiva, destacando-se ainda as cultivares "cherockee", delta, "du puits", vernal e moapa, (SAIBRO, 1984).

\section{6 - ESTABELECIMENTO DA CULTURA:}

Para a implantação da cultura da alfafa, o solo deve ser bem lavrado, gradeado e deixado em repouso para incorporação do calcáreo e ocorrência das reações. Quando existem camadas compactadas, deve ser feita subsolagem. O manejo do solo adequado antes da implantação da cultura é um dos itens de maior influência no estabelecimento da cultura. Observa-se, em áreas onde ocorre erosão, que o "stand" fica reduzido o solo 
compactado levando ao encrostamento, impedindo a infiltração da água, e o aproveitamento dos nutrientes aplicados na superficie, podendo ocorrer também infestação por ervas daninhas (SÁ \& PETRERE, 1991).

A calagem deve ser feita antes da semeadura, em quantidades de acordo com o PRNT ( Poder Relativo de Neutralização Total) equivalente ao produto disponivel. Ela é considerada fundamental para elevar o $\mathrm{pH}$ do solo visando neutralizá-lo, e neutralizar ou reduzir os efeitos tóxicos do $\mathrm{Fe}, \mathrm{Al}$ e/ou $\mathrm{Mn}$, melhorando o solo para que a alfafa possa aproveitar os nutrientes essenciais. A adubação e calagem devem ser feitas de acordo com as tabelas de recomendação de adubação, baseadas na análise de solo (NUERNBERG et al, 1990).

A importância da fixação biológica do nitrogênio é permitir a redução ou eliminação da necessidade de uso de adubos nitrogenados, reduzindo os custos de produção e eliminação de sub-produtos resultantes dos adubos nitrogenados (NUERNBERG et al, 1990). A utilização da inoculação das sementes com o Rhizobium meliloti é indispensável para o plantio, pois em solos tropicais não existe o Rhizobium específico para alfafa, e a nodulação para a fixação do nitrogênio será realizada através da bactéria simbionte Rhizobium meliloti que nodula as várias espécies do gênero medicago, e são capazes de fixarem nitrogênio em quantidade suficiente para suprir a cultura deste elemento (NUERNBERG, 1986). Um alfafal bem estabelecido é capaz de fixar $273 \mathrm{~kg} / \mathrm{N} / \mathrm{ha}$.ano, e o rhizobium é também responsável pela síntese de biotina, ácido pantotênico e vitamina B12 (BURTON, 1972).

Após o estabelecimento de uma espécie forrageira, quando são consideradas as questões de preparo de solo, correção, adubação semeadura e tratos culturais, surge a preocupação com o manejo, e deste dependerá a produção de matéria seca, persistência do stand e qualidade da forragem (JACQUES et al, 1982).

A alfafa é uma forrageira que apresenta uma boa produtividade e tem um excelente valor nutritivo (GONZALEZ et al, 1970). A digestibilidade é um critério muito 
importante para avaliar a forragem (GONZALEZ et al, 1972). Em geral se trabalha determinando o valor nutritivo a partir da composição química da forragem, pelo sistema convencional, ou através do sistema de VAN SOEST (1967), e informações adicionais podem ser conseguidas no trabalho de GOERING \& VAN SOEST (1970).

Havendo a necessidade da existência de um método para associar estágio morfológico e qualidade da forragem, alguns trabalhos foram desenvolvidos pelos pesquisadores KALU \& FICK $(1981,1983)$, visando facilitar a comunicação entre pesquisadores que estejam trabalhando com alfafa.

\subsection{CONSERVAÇÃO DA FORRAGEM ATRAVÉS DA FENAÇÃO}

De acordo com HONDA \& HONDA (1990), a fenação é um processo de conservação da alfafa obtido através do corte e desidratação, reduzindo seu teor de umidade de $70 \%$ a $90 \%$ para $12 \%$ a $15 \%$, através de processos naturais como calor do sol e vento e/ou artificiais, podendo desta forma ser armazenada com perdas mínimas de seu valor nutritivo, o que aproxima o feno, qualitativamente da alfafa que the deu origem. Sua execução é simples, pode ser realizado em grandes escala com auxilio da mecanização, apresenta facilidade no manuseio, armazenamento e fornecimento aos animais.

A fenação tem sido definida como um "meio de produzir um produto estável, de adequado valor nutritivo, com um mínimo de perdas e com um custo razoável de produção" (RAYMOND et al, 1978).

A maioria dos produtores que cultivam a alfafa no Brasil, têm como finalidade a comercialização da produção, sendo necessária a operação de fenação e enfardamento para facilitar o armazenamento e transporte (HONDA \& HONDA, 1990).

As práticas de conservação de forragens não melhoram a qualidade, ao contrário, podem piorá-la severamente se não forem usadas tecnologias recomendadas, e 
as perdas de matéria seca, especialmente de folhas, são os fatores que mais contribuem para a redução da forragem conservada (HOGLUND,1964 citado por NUERNBERG, 1986).

Para a produção de um bom feno, RAYMOND et al (1978) verificaram que $80 \%$ da água deve ser removida, sendo que $3 / 4$ desta umidade devem ser removidos no dia do corte. Após atingir $65 \%$ de umidade, a perda de água fica mais lenta.

Quando a umidade cai de 60 para $30 \%$ a água se difunde mais lentamente; as folhas secam primeiro e os caules mais grossos depois, levando a uma variação no conteúdo de umidade nas várias partes da planta. As folhas podem se perder nesta etapa, se houver muitas reviragens e a forragem estiver com menos de $40 \%$ de umidade. Se a temperatura nas pilhas ou fardos sobe acima de $32{ }^{\circ} \mathrm{C}$, significa que está ocorrendo respiração celular; as células morrem em torno de $45^{\circ} \mathrm{C}$. Acima deste nível, bactérias e fungos estarão atuando, podendo gerar até $40 \%$ de perdas; se o aquecimento for de $70^{\circ} \mathrm{C}$ estará ocorrendo oxidação química, e a $200^{\circ} \mathrm{C}$ ocorre combustão espontânea (RAYMOND et al, 1978).

2.7.1. Perdas durante o processo de secagem da alfafa:

Durante as operações de preparo do feno (corte, secagem e armazenamento) podem ocorrer perdas que variam de 10 a $50 \%$ de matéria seca (HOGLUND, 1964). A fenação se inicia pelo corte, com equipamentos manuais ou mecânicos. $O$ corte deve ser iniciado pela manhã, depois da evaporação do orvalho, quando o tempo está livre da possibilidade de chuvas. A fenação pode ser realizada por secagem ao sol, à sombra e/ou artificial ( NUERNBERG, 1986).

Nos vários estágios de crescimento da alfafa e no processo de fenação ocorrem diferenças na composição do material. A tabela 2 mostra os princípios nutritivos da alfafa nos vários estágios. 
TABELA 2: PRINCÍPIOS NUTRITIVOS DA ALFAFA (Medicago sativa L.) EM VÁRIOS ESTÁGIOS DE DESENVOLVIMENTO .

\begin{tabular}{|l|l|l|l|l|ll|l|}
\hline Estagio cresc. & PB (\%) & EE (\%) & ENN (\%) & FB (\%) & MM & (\%) & NDT (\%) \\
\hline Veget. & 26,53 & 3,79 & 29,36 & 20,37 & 9,95 & 59,77 \\
Folhas & 20,53 & 2,73 & 38,76 & 16,18 & 11,80 & 57,10 \\
Desidrat. & 17,18 & 2,43 & 37,29 & 23,20 & 9,80 & 52,98 \\
Início/flor & 16,87 & 3,00 & 36,00 & 25,50 & 8,63 & 54,86 \\
Total/flor & 14,62 & 3,00 & 34,88 & 29,25 & 8,25 & 47,98 \\
Feno bom & 16,07 & 2,03 & 37,23 & 26,23 & 8,44 & 52,59 \\
Feno méd & 13,93 & 1,73 & 36,62 & 30,30 & 7,42 & 51,47 \\
Feno ruim & 12,00 & 1,40 & 33,20 & 35,80 & 7,60 & 51,08 \\
Caules & 14,95 & 1,17 & 40,14 & 24,77 & 8,97 & 48,61 \\
\hline
\end{tabular}

Fonte: ANDRIGUETTO et al, 1992 (normas e padrões de nutrição e alimentação animal).

Estágio de Crescimento Vegetativo: Veget.=vegetativo, desidrat.=desidratado, feno méd = feno médio, Início/flor= início da floração, Total /flor=floração total, $\mathrm{PB}=$ proteína bruta, $\mathrm{EE}=$ extrato etéreo, $\mathrm{FB}=$ fibra bruta, $\mathrm{EN}=$ extrativo não nitrogenado, $\mathrm{MM}=$ matéria mineral, $\mathrm{ND}=$ nutrientes digestiveis totais.

Pode-se observar uma diminuição nos princípios nutritivos com a própria desidratação, e mais ainda com o processo de fenação, onde as perdas podem ser grandes, em especial de folhas. Segundo CARTER (1960), as perdas de proteína bruta podem chegar até $34 \%$ a campo e $24 \%$ no armazenamento.

Para uma boa qualidade de feno, o manejo deve permitir que $95 \%$ da água evapore o mais rápido possível .A forragem deve ser cortada, enfardada e estocada com o mínimo possível de perdas de matéria seca e nutrientes (RAYMOND et al, 1978). As práticas de manejo influenciam sobre a perda de água e também as perdas de matéria seca e qualidade, segundo um estudo feito por MACDONALD \& CLARK (1989). O 
conteúdo de umidade do feno requerido para prevenir a atividade microbiana é $10 \%$ no máximo (NASH, 1978), mas na prática é embalado e estocado com 15- $20 \%$ de umidade com baixos níveis de danos microbianos. Na Grã-Bretanha o feno pode ser armazenado com maior teor de umidade no inverno (18\%) do que no verão $(16 \%)$, porque o frio reduz a atividade microbiana, em especial de fungos (FELDMAN \& LIEVERS, 1978 E FRIESEN, 1978). A umidade para uma estocagem segura está inversamente relacionada com o tamanho e a forma dos fardos; os fardos pequenos e retangulares são de estocagem mais segura que os grandes fardos redondos (LARSEN \& RIDER, 1985).

A taxa de perda de água declina exponencialmente durante o processo de secagem, a diminuição na umidade da forragem requer progressivamente mais tempo, durante as fases de secagem, secando mais lentamente no final do processo (MACDONALD \& CLARK ,1989). Existem 2 fases de secagem: uma inicial, quando os estômatos estão abertos, a resistência da planta é mínima e o déficit de pressão de vapor entre os tecidos da planta e o ambiente é máximo. É uma fase rápida e difícil de ser detectada. $\mathrm{Na}$ fase seguinte os estômatos estão fechados. A cutícula, os estômatos e a camada externa são barreiras para a perda d'água (MACDONALD \& CLARK, 1989).

Se a forragem está com alta umidade, os tecidos jovens, reprodutivos, hastes e caules tendem a se compactar sobre o seu próprio peso, reduzindo a circulação de ar. $\mathrm{O}$ revolvimento das leiras é importante: NASH (1978) mostrou que a perda de água é de 0,5 a $1 \%$ por hora em leiras não revolvidas e de $2 \%$ por hora nas revolvidas, chegando até $3 \%$ nas que sofreram condicionamento e reviragem.

A fase final de secagem do feno, começa quando a umidade está em torno de $45 \%$, é mais sensitiva às condições climáticas que as outras fases (NASH, 1978).

Os fatores que influenciam a perda de água são: o potencial de evapotranspiração (PET) ou déficit de pressão de vapor (DPV), a umidade do solo e a densidade das leiras. As condições climáticas são bastante imprevisíveis para uma boa 
prática de fenação. MURDOCK (1980), relatou que havendo uma média de 2 a 2.5 dias de bom tempo, ou após 3 dias de bom tempo, pode se esperar que a fenação seja realizada com boa qualidade do feno. Mas é um fator empírico e dificil ser previsto, uma vez que a dependência do tempo contribui para o risco de confecção do feno.

A umidade relativa do ar é um importante fator para a secagem do feno. Por exemplo, uma alfafa arranjada em uma fina camada alcança $25 \%$ de umidade em 25 horas; já uma umidade relativa do ar de $45 \%$ requer 47 horas ou mais para a forragem alcançar o mesmo teor de umidade (CRUMP,1985). O feno é higroscópico, por isso a umidade relativa do ar influencia no equilíbrio da umidade da forragem até níveis de estocagem segura. NASH (1978) calcula que $80 \%$ de umidade relativa no ar estará em equilíbrio com $22 \%$ de umidade no feno, e $60 \%$ de umidade relativa seria um limite máximo para umidade no feno de $13 \%$.

WILMAN \& OWEN (1982) observaram que a rehidratação é maior em plantas imaturas que maduras. CLARK \& MACDONALD (1977) observaram que durante o dia há períodos desfavoráveis à perda d'água, como ao amanhecer e ao entardecer.

As folhas da planta são uma superfície de livre evaporação Estima-se que nas superficies acima e abaixo da folha existam entre 1090 e 880 estômatos $/ \mathrm{mm} 2$ respectivamente ( MACDONALD \& CLARK, 1989).

Em gramíneas os estômatos se fecham uma hora após corte (MURDOCK , 1980). HARRIS \& TULBERG (1980), verificaram que aproximadamente 20 a $30 \%$ da perda de água ocorre antes do fechamento dos estômatos, e este é um fator que diminui muito a desidratação da forragem. Pesquisas tem sido feitas no sentido de se encontrar substâncias que possam manter os estômatos abertos artificialmente. A substância fusicoccina produzida pelo fungo Fusicoccum amygdali, impede a oclusão dos estômatos (MORRIS, 1972 e TURNER, 1970). A aplicação de fusicoccina deve ser feita $3 \mathrm{~h}$ antes do corte, e a planta atinge $40 \%$ da umidade em metade do tempo que seria necessário que se não houvesse a aplicação (TURNER, 1970). Com o uso desta 
substância o tempo de secagem para alcançar 22\% de umidade, passa de 52 para 46 horas, ou de 4 para 3 dias (TURNER, 1970).

A cutícula consiste de cutina, um polímero extracelular e insolúvel, associado com ceras solúveis, que cobre a superfície externa das células epidérmicas formando uma camada contínua, constituindo-se de uma grande barreira que inibe a perda de água. Sua natureza hidrofóbica é devida à presença de ceras e longas cadeias de ácidos graxos esterificados com longas cadeias de álcoois monohídricos. Em consequência desta característica, os biocidas, reguladores de crescimento, ou fórmulas dessecantes devem conter em sua formulação um detergente para facilitar a sua penetração e atuação, removendo ou modificando a cutícula, aumentando a taxa de secagem (DERNEDDE 1980).

MEIDNER (1986), em uma revisão verificou que a resistência cuticular varia com a idade, temperatura e irradiação durante o crescimento, e com o grau de hidratação $\mathrm{da}$ folha, observou que os caules finos ( $2 \mathrm{~mm}$ ) secavam mais lentamente que os grossos ( $4 \mathrm{~mm})$, mas se a epiderme é removida, os caules finos secam 2 vezes mais rápido. Ele concluiu que a permeabilidade da cutícula aumenta com a idade, pois a espessura da cutícula diminui.

Como fator de manejo para secagem pode-se citar a resistência das "leiras". Para um conteúdo de umidade de $80 \%$ existe $1.25 \mathrm{~kg}$ de matéria seca e $5 \mathrm{~kg}$ de água por $/ \mathrm{m} 2$. A forragem cortada é disposta em uma pilha central ou disposta em fileiras (leiras), o que serve para limitar as ações climáticas e reduzir as perdas quando o feno é coletado pelo enfardadador ou levado para o barracão de secagem. A concentração da forragem em fileiras também reduz a superficie para incidência da radiação e aumenta a densidade do corte em 5 vezes mais do que se a forragem estivesse espalhada (LARSEN $\&$ RIDER 1985).

A estrutura fisica da leira ou da forragem espalhada é uma restrição à circulação do ar, e a prática de enleirar prolonga o tempo de secagem. JONES \& HARRIS (1980) 
verificaram que a resistência da leira à perda de água ocorre mais no início do ciclo de secagem.

CLARK \& MACDONALD (1977) demonstraram que há uma secagem mais rápida na parte externa da leira. A secagem lenta no interior da leira é devida à limitada penetração de energia, e do baixo potencial de evapotranspiração. JONES \& HARRIS (1980) verificaram que a radiação incidente a $2 \mathrm{~cm}$ de profundidade diminui à metade em relação à superficie e na base da leira chega a $10 \%$.

Essa heterogeneidade de umidade na leira pode ocorrer também nos fardos. Os pesquisadores WILMAN \& OWEN (1982) observaram que existe uma secagem mais rápida em leiras mais finas do que nas leiras mais grossas. $\mathrm{Na}$ secagem final, as leiras finas apresentam desvantagens pois tem maior propensão de reabsorver a água do solo, chuva e orvalho.

Recomenda-se pois deixar um "resíduo" ou seja, não cortar a forragem rente ao solo, promovendo assim um menor contato com o solo e maior circulação embaixo das leiras; cortar áreas menores para correr menos riscos com a ação deletéria de condições climáticas desfavoráveis (MACDONALD \& CLARK, 1989). Uma das opções é secar a campo até 30 a $40 \%$ de umidade e depois secar à sombra em um barracão, processo muito utilizado na região norte do Paraná., ou enfardar com 20 a $30 \%$ de umidade utilizando preservativos químicos (KNAPP et al, 1976).

As leguminosas secam mais lentamente que as gramineas por apresentarem umidade inicial maior e uma grande proporção caule/folha (CIOTTI \& CAVALLERO 1980). Devido ao seu alto valor nutricional e ao alto custo dos adubos nitrogenados, são mais manejadas e fenadas que as gramíneas, principalmente nos EUA. São manejadas e fertilizadas com mais cuidado, resultando em um "stand" mais denso, e um feno de melhor qualidade. THOMAS et al (1981) relataram que a alfafa madura seca mais rápido quando comparada ao estágio de início do florescimento. Do grupo das 
leguminosas é a que seca mais rápido e, portanto, a mais escolhida para a prática de fenação .

HARRIS \& TULBERG (1980), revisando a literatura sobre transferência de água do caule para as folhas, concluíram que a transpiração das folhas afeta substancialmente a perda de umidade do caule. TULBERG (1975) demonstrou que $35 \%$ da água do caule é perdida através das folhas e este sistema continua até o teor de umidade atingir $40 \%$, e que a secagem inicial é $153 \%$ mais rápida que a final.

CARTER (1960), em revisão, verificou que as perdas no corte estão em torno de $25 \%$. A porcentagem de proteína bruta perdida em feno curado a campo pode ser de $34 \%$. WILKINSON (1981) verificou uma queda na ingestão de $18 \%$ em relação ao produto fresco, e este decréscimo foi atribuído à diminuição dos constituintes solúveis e aumento dos componentes da parede celular, decorrentes da respiração celular, perda de folhas e danos provocados pelas condições climáticas desfavoráveis.

As perdas de matéria seca podem ser consideradas em três fases: primeiramente por perdas respiratórias e em decorrência de condições climáticas desfavoráveis durante a secagem; em segundo, por perdas na colheita associadas com corte, condicionamento, enleiramento, tombamento e enfardamento, e em terceiro, durante a estocagem e 0 manuseio (MACDONALD \& CLARK, 1989). A respiração microbiana e da planta durante a secagem podem reduzir o rendimento da colheita em até 2- $8 \%$ (em boas condições climáticas) e $16 \%$ em condições climáticas ruins. Quando a secagem é atrasada pelo excesso de umidade, $30 \%$ da matéria seca pode ser perdida devido à respiração, (REES,1982). A rehidratação devido ao orvalho e chuvas prolonga a respiração e aumenta as perdas gerais. SIMPSON (1961) verificou que utilizando um sistema de comprimir os caules, acelerou o processo de secagem e as perdas com respiração diminuíram.

A exposição mais prolongada a campo pode levar a planta à perda de nutrientes por lixiviação em condições climáticas desfavoráveis, e à perdas de matéria 
seca, como também de digestibilidade, de nutrientes solúveis, folhas e flores, e ainda ficando mais sujeita à ação dos fungos (MACDONALD \& CLARK, 1989).

As perdas ocorridas dependem do tipo de corte e/ou condicionamento realizado, o tempo de enleiramento/espalhamento, do tipo de fardo utilizado e da umidade da forragem ao corte (KLINNER \& SHEPPERSON, 1975).

O corte mecânico forma leiras compactas de 1,0 m de largura e altura de corte 5-10 cm acima do solo. Esta afeta o rendimento e a qualidade do feno (TAYLOR \& RUDMAM, 1965). KLINNER (1975) verificou que as perdas por segadeiras mecânicas de barra foram menores que com a segadeira rotativa, possivelmente devido ao grande atrito e velocidade desta última.

$\mathrm{O}$ acondicionamento mecânico destina-se a aumentar a taxa de evaporação da umidade da forragem, reduz a resistência cuticular por esmagamento ou prensagem com quebra da cutícula ou abrasão realizada através de escovas. Se realizado em condições climáticas favoráveis pode acelerar o processo de secagem em $75 \%$, durante a fase inicial da secagem, com menor efeito nas fases posteriores ROTZ et al (1984). DERNEDDE (1980), verificou que o condicionamento mecânico pode colaborar com o aumento a taxa de secagem. O efeito no início da secagem é maior que no final, e o método de abrasão mecânica tem proporcionado bons resultados.

$\mathrm{O}$ acondicionamento é mais eficaz para leiras mais finas, e pode aumentar o risco de perdas por lixiviação se o corte for sujeito a chuvas durante a secagem. As perdas de matéria seca em feno condicionado acabam sendo menores, porque decrescem o tempo de secagem, (MARTIN, 1980).

$\mathrm{O}$ acondicionamento químico refere-se à utilização de agentes químicos que alteram a resistência cuticular, aumentam a taxa de secagem. Secagem mais rápida significa aumento no rendimento e qualidade do feno, reduzindo as perdas respiratórias, e diminuição dos danos por ação do clima. Entre alguns produtos utilizados estão o herbicida Paraquat $\Theta$, carbonato de potássio e outros agentes que podem ser utilizados. 
O que HARRIS \& TULBERG (1980) discutem a respeito da utilização de agentes químicos é um possível efeito sobre o consumo e aceitabilidade pelo animal. A excessiva quantidade de água requerida para espalhar o produto e a falta de uniformidade de aplicação. $\mathrm{O}$ acondicionamento mecânico e/ou químico pode acelerar a taxa de secagem da alfafa desde que devidamente utilizado.

O carbonato de potássio age modificando a estrutura da cutícula. Aumenta em $47 \%$ a secagem por redução da resistência cuticular CRUMP (1985). A retenção de água por forças osmóticas aumentam durante o processo de secagem, BOON LONG (1941) citado por MACDONALD \& CLARK (1989) verificou que aumentando o potencial osmótico das folhas, com introdução de glucose ou aumento da irradiação diminui a permeabilidade da célula à água e diminuem as taxas de transpiração. Os fatores intra e extracelulares a partir dos estômatos e resistência cuticular, retardam a secagem na fase final ( JONES \& HARRIS 1980).

BUCKMASTER \& HEINRICHS (1993) em uma pesquisa feita com feno de alfafa, utilizando preservativos (ácido propiônico $0,2-0,3 \%$ peso úmido) observaram que o preservativo não é bom para feno de alta umidade, $(>30 \%)$, mas mostrou benefícios para feno de baixa umidade. $\mathrm{O}$ ácido propiônico reduz a perda de MS na estocagem, e o produto não tem efeitos significativos sobre a qualidade final do feno.

PATIL et al (1993), trataram mecanicamente alfafa fresca e pré-secada, e conseguiram a redução no tempo de secagem em até $40 \%$. Com o acondicionamento químico, usando o carbonato de potássio, reduziram o tempo de secagem em $50 \%$.

A movimentação da forragem promove secagem por aumento do fluxo de ar e aumento da penetração da energia radiante na leira (NASH,1978). Os enleiradores mecânicos são mais vistos na Europa, pois o feno produzido é de boa qualidade e feito com gramíneas, e estas resistem mais ao manuseio que as leguminosas (MACDONALD \& CLARK, 1989). A grande agitação mecânica promovida por estes enleiradores faz com que a alfafa, por exemplo, perca as folhas. Estima-se a perda na alfafa de 15 a $35 \%$ 
e nas gramíneas de 10 a 15\% (FRIESEN, 1978). Os melhores resultados encontrados são revolvendo a alfafa cortada logo após o corte e não 1 a 2 dias após corte (JONES \& HARRIS, 1980). O melhor momento para reviragem é quando o teor de umidade varia de 50 a $67 \%$. A reviragem é mais apropriada em formas imaturas que maduras, pois nestas últimas é maior a perda de folhas (JONES \& HARRIS, 1980). A ação mais vigorosa das reviragens é feita no inicio do ciclo, e se é necessário revolver forragem seca, uma forma de revolver mais suave é mais recomendada, as perdas variam, neste caso de 5 a $15 \%$ (MACDONALD \& CLARK, 1986).

Para o enfardamento da alfafa, podem ser feitos fardos redondos ou retangulares. Para a confecção dos fardos redondos é necessário equipamento próprio. Esta modalidade tem grande potencial para alimentação de rebanhos, mas apresenta perdas na estocagem. Os fardos convencionais retangulares são vulneráveis à ação do tempo e requerem uma área coberta para armazenamento; entretanto são de manuseio mais fácil, e também existem vagões propulsores de fardos que facilitam o transporte (LARSEN \& RIDER, 1985).

As perdas de matéria seca que podem ocorrer nos fardos, são devidas ao teor de umidade excessiva, causando atividade microbiana, aquecimento, perdas respiratórias, mudanças na composição química e decréscimo da proteína e energia. Em casos de matéria seca muito alta, pode-se enfardar após a queda do orvalho, para reduzir as perdas no enfardamento. Nos fardos retangulares as perdas vão de 3-8\% e nos redondos de 1-15\% (MARTIN, 1980).

As perdas relacionadas com transporte variam de 1-10\% de acordo com o tipo de forragem e o tempo que permaneceram no campo. As perdas de proteina bruta na estocagem variam de 18 a $29 \%$ para fardos redondos no galpão e a campo, respectivamente (CLARK \& MACDONALD, 1989).

As características associadas com boa qualidade do feno de alfafa são: cor verde brilhante, alta relação folha/haste, ausência de odores e poeiras que indiquem 
mofo ou bolor. Fardos embalados a uma umidade acima de $20 \%$ deterioram durante a estocagem devido à degradação microbiana e aquecimento (KLINER \& SHEPERSON 1975). Temperatura acima de $70^{\circ} \mathrm{C}$ indica atividade microbiana e oxidação exotérmica. Segundo NASH (1978), o padrão típico de aquecimento em fardos é apresentar 2 picos de elevação de temperatura: o primeiro dentro de 2-3 dias, que é a respiração celular; o segundo dentro de 7-10 dias que é a respiração dos fungos. O Aspergillus glaucus pode ser um dos fungos responsáveis pelo calor e quebra de carboidratos complexos e proteínas (MARTIN, 1980).

Alfafa embalada a $27 \%$ de umidade sofre aquecimento mais em fardos redondos que em fardos tradicionais (retangulares), (SCALES ET AL, 1978).Feno com bolor, além de baixa qualidade, pode causar problemas à saúde do gado e operadores. Especialmente em climas úmidos, os microorganismos Thermophylie actinomycetos em particular Microplyspora faeno e Thermoactinomyces vulgaris são favorecidos pelas altas temperaturas, e podem causar problemas pulmonares no gado e em pessoas que manipulem o feno, (NASH, 1978).

As perdas no fornecimento de feno aos animais podem ser minimizadas, se forem construídas grades especiais para feno ao invés de cochos grandes e no chão.No primeiro caso essas perdas serão em torno de $3.7 \%$, já em montes grandes alcançará cerca de $35-46 \%$ (LECHTENBERG, 1978).

O principal objetivo da fenação é obter um produto de qualidade com pouca perda de matéria seca. Deve-se utilizar o equipamento que cause o menor dano possivel, sendo recomendada a segadeira rotativa (causa menor dano). Para acondicionamento físico, a abrasão é mais recomendada, e deve-se empregar o ancinho para reviragens para uma secagem mais rápida (FELDMAN \& LIEVERS, 1978). O enfardamento tem sido preferido em fardos redondos nos EUA, e no Brasil em fardos convencionais (retangulares). As perdas de qualidade em termos de proteína bruta, carboidratos não estruturais, digestibilidade e ingestão, podem ser estimadas em até $50 \%$. As limitações 
climáticas impõem alguns riscos, especialmente em regiões úmidas. As leguminosas são mais susceptiveis ao manuseio e às perdas (MACDONALD \& CLARK, 1989).

De acordo com HART \& BURTON (1967), quando o feno é secado, a remoção rápida de água é importante para a perda de nutrientes ser mínima. Em seu trabalho verificaram que a forragem partindo de $70 \%$ de umidade, no primeiro dia o teor de umidade diminui para $51 \%$, a uma radiação de $260 \mathrm{cal} \mathrm{cm} 2 /$ dia e déficit de pressão de vapor de $36 \mathrm{~mm} / \mathrm{Hg}$. Em dias com boa radiação solar e bom déficit de pressão de vapor, por exemplo, com radiação de $594 \mathrm{cal} \mathrm{cm} 2 /$ dia e déficit de pressão de vapor de 150 mmHg, o nível de umidade pode cair para $29 \%$. O conteúdo inicial de umidade da forragem é bastante importante e é influenciado pelo DPV (déficit de pressão de vapor) do ar, radiação solar e rendimento em alfafa.

A proteína bruta e a matéria seca digestível decrescem pouco em um feno bem curado, em boas condições climáticas, e a perda é grande em tempo chuvoso. As perdas de caroteno estão associadas com a radiação recebida. A chuva durante a fenação pode produzir perdas muito maiores do que o atraso no corte; ou seja, é melhor passar do ponto ótimo de corte para esperar bom tempo, do que cortar com tempo chuvoso. A energia solar é atenuada próximo à superficie do solo e com pouca ventilação há aumento da umidade. Os fatores de campo influenciam no inicio da secagem, bem como densidade e altura de corte. Alta irradiação e baixa umidade são requeridos para uma boa fenação. O conteúdo inicial de umidade da forragem de alfafa é em torno de 75 a 85\% (7 ton. MS/ha), o qual para ser reduzido para $20 \%$ tem que haver uma remoção de 25 toneladas de água (MACDONALD \& CLARK, 1989).

ROTZ \& ABRAMS (1988) verificaram que existem limites da planta para perda de água, e fatores de campo ( área das leiras) que restringem a circulação de ar. A perda de água em uma camada fina a $20^{\circ} \mathrm{C}$ e umidade relativa a $50 \%$, e o vento à velocidade de $1 \mathrm{~m} / \mathrm{s}$ leva a uma taxa de secagem de $1 \mathrm{~g}$ de água/g MS.hora, e a taxa de perdas de MS gira em torno de $0.01 \mathrm{~g} / \mathrm{g}$ MS / hora. 
Verifica-se que 20 a $25 \%$ de umidade, ou 0,25 g/g. MS é conseguida em 50-60 $\mathrm{h}$ de secagem. Em uma leira típica $15-20 \mathrm{~cm}$ de altura e $100-125 \mathrm{~cm}$ de comprimento, o início da secagem na leira é desfavorável; depois com a perda de água e a diminuição da densidade, o fluxo de ar é melhor no interior da leira. Leiras menos densas são melhores para uma melhor evaporação. Uma sugestão é cortar a área toda e espalhar no campo formando leiras menos densas. Revolver a forragem para passar de $4 \mathrm{~g}$ de água por grama de matéria seca até alcançar $0,25 \mathrm{~g}$ de água por grama de matéria seca para estocagem segura. No periodo final de secagem pode-se juntar mais leiras, pois a densidade é menor. Durante a fase inicial a secagem é influenciada pelo microclima na leira, mas na fase final já não existe tanta influência. Estudos para melhorar a taxa de evaporação na leira são necessários ( MACDONALD \& CLARK, 1989).

ROTZ \& ABRAMS (1988) também descreveram as perdas de MS da seguinte forma: $3,5 \%$ para o corte, $0,8 \%$ para o revolvimento nas leiras ( revolvimento mecânico), 11,8 \% no enfardamento mecânico e $1,1 \%$ no fardo. Na estocagem : 4,2 \% em feno seco ( $11-20 \%$ de umidade), 7,9\% para feno com $25-34 \%$ de umidade e $10,9 \%$ para feno com 25-34\% de umidade. As perdas de MS durante o corte e estocagem, giram em torno de $15-25 \%$ para o feno feito em boas condições climáticas e $35-100 \%$ em feno feito em condições climáticas desfavoráveis.

Os constituintes mais importantes para o valor nutritivo da forragem são a proteína e os carboidratos, e estes últimos são os mais susceptíveis a perdas (REES, 1982). As perdas ocorrem desde a forragem em pé até a operação de enfardar, incluindo a respiração da planta e dos microrganismos presentes na planta, que se relacionam com o teor de umidade, segundo (REES,1982). A respiração cessa quando o teor de umidade chega a 40\% (WOLF \& CARSON 1973). As perdas com respiração estão em torno de $5-10 \%$ de matéria seca (carboidratos não estruturais). A chuva causa perda de folhas e lixiviação dos materiais solúveis, chegando a $20 \%$ na fase inicial de secagem, considerando-se que as perdas iniciais com respiração podem chegar a $40 \%$. 
As perdas de MS com as operações mecânicas são de 1-3\% para o corte, 1-2\% para as reviragens, 3-6\% para o transporte e $2-10 \%$ para o enfardamento, segundo KOEGEL ET AL (1985) E ROTZ \& SPROT (1984).

ROTZ \& ABRAMS (1988) verificaram que as perdas de MS a campo são pequenas se o feno é curado sem chuva, com chuva chegam a $11 \%$.As perdas com maquinários foram $3.5 \%$ para transporte, $8 \%$ para enfardar e $1.1 \%$ no fardo; na estocagem $4,5 \%$ para feno seco (até $20 \%$ umidade), e $10,9 \%$ para feno com umidade de $25-34 \%$.

Nas folhas imaturas com alta concentração de açucares, deve-se reduzir para $12 \%$ a umidade de estocagem, pois a presença dos açucares as torna mais higroscópicas, e podem reabsorver água. As forragens mais maduras podem ser armazenadas com 15$18 \%$ de umidade, pois são menos higroscópicas (RAYMOND et al, 1978).

BUCKMASTER et al (1989) incorporaram em um modelo matemático, valores de perdas na alfafa através de colheita, estocagem, e fornecimento aos animais e também valores relacionados à condições climáticas no DAFOSYM (dairy forage system). $\mathrm{O}$ valor individual e combinado foi simulado para 100 vacas leiteiras. Os valores das perdas refletiram o impacto das perdas na quantidade e valor nutritivo da alfafa disponível para o consumo animal. A perda de matéria seca da alfafa associada com a queda na qualidade resultou em uma média de custo anual de U\$ 12.060,00 em um rebanho de 100 vacas. As maiores perdas foram com silagem U\$ 8.90/ton. MS, feno U\$ 8.40/ton. MS, estocagem e transporte U\$ 5.40/ton. MS. A perda total de MS foi de aproximadamente $25 \%$ para feno e silagem combinados.

COLLINS $(1985,1991)$ verificou que a quantidade e composição das folhas foram os principais responsáveis pelos efeitos na fenação; reidratação do feno, quantidade e qualidade do produto final. $\mathrm{O}$ componente folha contém um terço da matéria seca e metade da digestibilidade mas foi responsável por mais de $60 \%$ das perdas 
de MS e digestibilidade. O NDF (fibra em detergente neutro) é negativamente afetado pela cura do feno e teor de umidade ALLEN et al (1992).

Em uma pesquisa feita por FONTES et al (1993), assumindo os valores médios da proteína bruta de $37,5 \%$ e $17,1 \%$, contidos na folha e no caule respectivamente, e produções de matéria seca de 14.097 e $12.775 \mathrm{Kg}$ /ha.ano, foram produzidos 7471 $\mathrm{kg} / \mathrm{ha} / \mathrm{ano}$ de proteína, sendo que $71 \%$ foram obtidos das folhas.

Segundo BASSOLS \& PAIM (1978), a cultivar crioula apresentou uma produção de matéria seca e proteína bruta maior que as outras cultivares, sendo recomendado seu cultivo no Rio Grande do Sul. Outras cultivares que se destacaram foram a "dupuis" e a vernal. As maiores produções de proteína foram no estádio de préflorescimento. A variedade crioula tem se destacado entre as variedades de alfafa, com boa produtividade e resistência (ARAÚJO FILHO et al ,1972). 


\section{MATERIAL E MÉTODOS:}

\subsection{LOCAL:}

O experimento foi conduzido em 3 propriedades na cidade de Itambaracá, na região norte do Paraná. Esta região apresenta clima tropical de altitude, com média anual de temperatura entre $17-22^{\circ} \mathrm{C}$. Segundo a classificação de Köppen é ( Cfa), subtropical úmido com verões quentes, e pluviosidade de $1500 \mathrm{~mm}$ anuais. $\mathrm{O}$ tipo de solo encontrado é latossolo roxo eutrófico.

A variedade da alfafa plantada é a crioula. O manejo e os tratos culturais realizados são os mesmos nas 3 propriedades, ou seja, a cultura foi implantada aproximadamente na mesma época, em torno de abril de 1992, o tipo de solo é o mesmo, latossolo roxo eutrófico, as áreas são aproximadamente do mesmo tamanho, cerca de 2,5 ha cada. Os tratos culturais realizados em geral são semelhantes, é feita uma calagem quando a cultura é implantada, e uma adubação inicial, com fertilizantes ou adubos orgânicos, depois em geral não é feita adubação de cobertura nem de reposição, só se houver algum problema, e aplicação de inseticidas se for necessário. O corte é realizado com alfanjes manuais, e o material cortado é enleirado com ancinhos manuais e também com ancinhos à tração animal, o material cortado é levado para um barracão, onde permanece de 5-15 dias, depois é enfardado e comercializado. As épocas de corte comerciais são aproximadamente as mesmas, assim como o estágio vegetativo ao corte (tabela 3).

Tabela 3: Estágio vegetativo da planta em cada corte:

\begin{tabular}{lll}
\hline Propriedades/Períodos & Período 1 & Período 2 \\
\hline Propriedade 1 & $50 \%$ de brotação basilar & $50 \%$ de brotação basilar \\
Propriedade 2 & $50 \%$ de brotação basilar & $50 \%$ de brotação basilar \\
Propriedade 3 & início da brotação basilar & $20 \%$ de brotação basilar \\
\hline
\end{tabular}




\subsection{MATERIAL UTILIZADO:}

As coletas de amostras foram realizadas em 2 periodos consecutivos de corte, e 5 fases distintas (tratamentos), como se observa na tabela 4.

Tabela 4: Datas de corte de alfafa e coleta nas 3 propriedades estudadas:

\begin{tabular}{lllllll}
\hline & \multicolumn{2}{l}{ Propriedade 1 } & \multicolumn{2}{l}{ Propriedade 2 } & \multicolumn{2}{l}{ Propriedade 3 } \\
\hline Fases & Período 1 & Período 2 & Período 1 & Período 2 & Período 1 & Período 2 \\
\hline $\mathbf{1}$ & $28 / 06 / 94$ & $17 / 08 / 94$ & $27 / 06 / 94$ & $15 / 08 / 94$ & $11 / 07 / 94$ & $16 / 08 / 94$ \\
$\mathbf{2}$ & $28 / 06 / 94$ & $17 / 08 / 94$ & $27 / 06 / 94$ & $15 / 08 / 94$ & $11 / 07 / 94$ & $16 / 08 / 94$ \\
$\mathbf{3}$ & $29 / 06 / 94$ & $18 / 08 / 94$ & $28 / 06 / 94$ & $16 / 08 / 94$ & $12 / 07 / 94$ & $17 / 08 / 94$ \\
$\mathbf{4}$ & $30 / 06 / 94$ & $19 / 08 / 94$ & $29 / 06 / 94$ & $17 / 08 / 94$ & $13 / 07 / 94$ & $18 / 08 / 94$ \\
$\mathbf{5}$ & $13 / 07 / 94$ & $24 / 08 / 94$ & $13 / 07 / 94$ & $22 / 08 / 94$ & $18 / 07 / 94$ & $22 / 08 / 94$ \\
\hline
\end{tabular}

Fases*: Fase 1: planta verde antes do corte

Fase 2: $2 \mathrm{~h}$ pós corte (a campo)

Fase 3: 24 h pós corte ( a campo )

Fase 4: $36 \mathrm{~h}$ pós corte ( a campo )

Fase 5: Ponto de feno ( barracão)

Os cortes foram iniciados em geral pela manhã, em torno das 7 horas, com alfanges manuais, deixando-se uma camada fina de alfafa cortada sobre o solo em toda a área de corte. $O$ material cortado era revolvido com ancinhos manuais cerca de 3 a 4 horas após o corte, e, no final do dia, cerca de 10-12 horas após o corte. Todo material cortado foi recolhido em leiras compridas com auxilio de ancinho fixo de tração animal e ancinhos manuais, permanecendo a campo enleirado durante a noite. No segundo dia, cerca de 24 horas após o corte, o material foi espalhado para a secagem final. Ao final do segundo dia, 36 horas após o corte, agrupou-se o material em "bolas", ou montes, com ancinhos manuais para facilitar o transporte ao barracão para a secagem final até o ponto de feno. 
Nesta última fase, a alfafa cortada foi recolhida ao barracão, onde foi revolvida 2 vezes por dia, pela manhã e à tarde, com ancinhos manuais durante 4 a 15 dias, dependendo do período e da propriedade, até atingir o "ponto de feno", ou seja, um teor de umidade em torno de 10 a $15 \%$. Após este período, o material foi enfardado com enfardadeira mecanizada a trator, para posterior comercialização.

As amostras para análises foram coletadas, de uma forma totalmente casualizada com lançamento de um quadrado de $50 \times 50 \mathrm{~cm}$, e a área coberta pelo quadrado foi colhida na altura de corte utilizada (a cerca de $5 \mathrm{~cm}$ do solo), em cada fase descrita anteriormente com quatro repetições cada uma, pesando cerca de 200 gramas. Em seguida foram acondicionadas em sacos individuais de papel, perfurados e previamente pesados. Após serem pesadas as amostras foram levadas à estufa à $65^{\circ} \mathrm{C}$, com circulação de ar forçada, onde permaneceram pôr $72 \mathrm{~h}$ até peso constante para determinação da MS ( matéria seca).

\subsection{ANÁLISES REALIZADAS:}

Foram determinados nas amostras : matéria seca (MS), relação haste/folha (RHF), proteína bruta $(\mathrm{PB})$, extrato etéreo ( $\mathrm{EE})$, fibra bruta $(\mathrm{FB})$, extrativo não nitrogenado $(\mathrm{ENN})$, matéria mineral $(\mathrm{MM})$ e nutrientes digestíveis totais (NDT). As determinações foram feitas no laboratório de bromatologia do Departamento de Zootecnia da Esalq, segundo as normas da A.O.A.C. (ASSOCIATION OF OFFICIAL AGRICULTURAL CHEMISTS, 1970).

Para determinação da relação haste/folha (RHF), foram coletadas amostras separadamente das utilizadas para determinação de matéria seca, porém nos mesmos períodos e fases. Em cada fase, dentro de cada período foram coletadas 4 repetições com cerca de 100 gramas cada uma e levadas para estufa a $65^{\circ} \mathrm{C}$ por $72 \mathrm{~h}$. Após este período a amostra total foi pesada e separadas as hastes das folhas, pesando-se separadamente cada uma para se estabelecer a relação haste/folha. 
A determinação do NDT ( nutrientes digestiveis totais) seguiu o sistema de equações proposto por KEARL (1982).

Os dados de precipitação, temperatura, umidade relativa do ar e radiação solar, registrados no período foram coletados através do posto metereológico localizado na F,F.A.L.M. (Fundação Faculdade de Agronomia Luiz Meneghel), a cerca de $12 \mathrm{Km}$ das áreas amostradas, e fornecidos pelo IAPAR ( Instituto Agronômico de Pesquisas do Paraná).

A produção de matéria seca foi calculada a partir do peso total do feno produzido na área nos dois períodos e transformada para matéria seca.

A variação da porcentagem de proteína ( perda) foi calculada por diferença entre a porcentagem inicial de proteína bruta na planta verde e a porcentagem de proteína bruta, em cada fase e no feno e os dados foram resumidos em um quadro para cada propriedade. 


\section{4 .DELINEAMENTO EXPERIMENTAL:}

O delineamento experimental utilizado em cada propriedade foi o inteiramente casualizado, com 4 repetições sendo avaliadas as 5 fases ( 1 a 5 ).

Modelo Estatístico Utilizado:

$$
Y_{i j}=\mu+F_{i}+e_{i j}
$$

onde :

$\mathrm{Y}=$ valor observado, $\mu=$ média,$F=$ fase, $\mathrm{e}=$ erro

$\mathrm{i}=$ índice de fase, $\mathrm{j}=$ índice de repetição

\section{QUADRO DE ANÁLISE DE VARIÂNCIA*}

CV (causa de variação) G.L .( graus de liberdade)

\begin{tabular}{ll}
\hline Fase (F) & 4 \\
Resíduo (B) & 15 \\
\hline
\end{tabular}

Total

19

* Para cada propriedade e período 


\section{RESULTADOS :}

TABELA 5: PRINCÍPIOS NUTRITIVOS BRUTOS- PROP 1/PER1

\begin{tabular}{lrrrrr}
\hline FATOR & \multicolumn{5}{c}{ FASES } \\
\cline { 2 - 6 } & \multicolumn{1}{c}{1} & \multicolumn{1}{c}{3} & \multicolumn{1}{c}{4} & \multicolumn{1}{c}{5} \\
\hline \% MS & $27,57 \mathrm{a}$ & $79,27 \mathrm{~b}$ & $85,75 \mathrm{c}$ & $87,22 \mathrm{c}$ & $89,92 \mathrm{c}$ \\
RHF & $0,86 \mathrm{a}$ & $0,79 \mathrm{a}$ & $1,23 \mathrm{~b}$ & $1,57 \mathrm{c}$ & $1,60 \mathrm{c}$ \\
$\%$ PB & $18,30 \mathrm{a}$ & $17,40 \mathrm{a}$ & $16,82 \mathrm{~b}$ & $16,22 \mathrm{~b}$ & $15,15 \mathrm{c}$ \\
\%FB & $22,92 \mathrm{a}$ & $23,15 \mathrm{a}$ & $25,03 \mathrm{~b}$ & $25,17 \mathrm{~b}$ & $26,90 \mathrm{~b}$ \\
\%EE & $1,15 \mathrm{a}$ & $1,17 \mathrm{a}$ & $1,49 \mathrm{a}$ & $1,48 \mathrm{a}$ & $2,50 \mathrm{~b}$ \\
\%MM & $9,37 \mathrm{a}$ & $9,77 \mathrm{a}$ & $6,95 \mathrm{a}$ & $8,25 \mathrm{a}$ & $9,09 \mathrm{a}$ \\
\%ENN & $46,12 \mathrm{a}$ & $46,48 \mathrm{a}$ & $47,85 \mathrm{a}$ & $49,88 \mathrm{a}$ & $51,37 \mathrm{a}$ \\
\%NDT & $57,49 \mathrm{a}$ & $56,80 \mathrm{a}$ & $58,79 \mathrm{a}$ & $60,58 \mathrm{a}$ & $55,89 \mathrm{~b}$ \\
\hline
\end{tabular}

Médias seguidas de letras minúsculas distintas nas colunas diferem pelo teste Tukey $(\mathrm{p}<0,05)$

TABELA 6: PRINCÍPIOS NUTRITIVOS BRUTOS- PROP1/ PER 2

\begin{tabular}{lrrrrr}
\hline FATOR & \multicolumn{5}{c}{ FASES } \\
\cline { 2 - 6 } & \multicolumn{1}{c}{ 1 } & \multicolumn{1}{c}{3} & \multicolumn{1}{c}{4} \\
\hline \%MS & $31,43 \mathrm{a}$ & $35,02 \mathrm{a}$ & $41,42 \mathrm{~b}$ & $75,85 \mathrm{c}$ & $84,47 \mathrm{~d}$ \\
RHF & $0,61 \mathrm{a}$ & $0,88 \mathrm{~b}$ & $0,97 \mathrm{c}$ & $1,09 \mathrm{c}$ & $1,36 \mathrm{~d}$ \\
$\%$ PB & $18,72 \mathrm{a}$ & $17,12 \mathrm{a}$ & $16,12 \mathrm{~b}$ & $15,70 \mathrm{~b}$ & $14,90 \mathrm{c}$ \\
$\%$ FB & $20,72 \mathrm{a}$ & $20,73 \mathrm{a}$ & $19,82 \mathrm{a}$ & $26,55 \mathrm{~b}$ & $28,32 \mathrm{~b}$ \\
$\%$ EE & $1,66 \mathrm{ab}$ & $1,87 \mathrm{~b}$ & $1,26 \mathrm{a}$ & $1,21 \mathrm{a}$ & $1,07 \mathrm{a}$ \\
$\%$ MM & $8,42 \mathrm{a}$ & $7,46 \mathrm{a}$ & $8,33 \mathrm{a}$ & $8,61 \mathrm{a}$ & $8,42 \mathrm{a}$ \\
$\%$ ENN & $50,47 \mathrm{a}$ & $52,82 \mathrm{a}$ & $54,52 \mathrm{a}$ & $49,97 \mathrm{a}$ & $49,22 \mathrm{a}$ \\
$\%$ NDT & $61,48 \mathrm{a}$ & $60,95 \mathrm{a}$ & $59,73 \mathrm{a}$ & $56,66 \mathrm{~b}$ & $55,64 \mathrm{~b}$ \\
\hline
\end{tabular}

Médias seguidas de letras minúsculas distintas nas colunas diferem pelo teste Tukey $(\mathrm{p}<0,05)^{*}$ 
TABELA 7: PRINCÍPIOS NUTRITIVOS BRUTOS - PROP2/ PER1:

\begin{tabular}{lrrrrr}
\hline FATOR & \multicolumn{5}{c}{ FASES } \\
\cline { 2 - 6 } & \multicolumn{1}{c}{2} & \multicolumn{1}{c}{3} & \multicolumn{1}{c}{4} \\
\hline \% MS & $32,47 \mathrm{a}$ & $48,47 \mathrm{~b}$ & $87,50 \mathrm{c}$ & $88,37 \mathrm{c}$ & $89,05 \mathrm{c}$ \\
RHF & $0,74 \mathrm{a}$ & $0,76 \mathrm{a}$ & $1,41 \mathrm{~b}$ & $1,48 \mathrm{~b}$ & $1,60 \mathrm{c}$ \\
$\%$ PB & $19,35 \mathrm{a}$ & $18,35 \mathrm{a}$ & $16,50 \mathrm{~b}$ & $15,50 \mathrm{~b}$ & $15,25 \mathrm{~b}$ \\
$\%$ FB & $27,02 \mathrm{a}$ & $27,32 \mathrm{a}$ & $26,22 \mathrm{a}$ & $26,63 \mathrm{a}$ & $28,80 \mathrm{~b}$ \\
EE & $1,29 \mathrm{a}$ & $1,65 \mathrm{a}$ & $1,42 \mathrm{a}$ & $1,41 \mathrm{a}$ & $1,28 \mathrm{a}$ \\
MM & $8,73 \mathrm{a}$ & $7,89 \mathrm{a}$ & $8,43 \mathrm{a}$ & $8,33 \mathrm{a}$ & $7,52 \mathrm{a}$ \\
ENN & $43,55 \mathrm{a}$ & $44,77 \mathrm{a}$ & $47,42 \mathrm{a}$ & $48,12 \mathrm{a}$ & $49,12 \mathrm{a}$ \\
NDT & $57,89 \mathrm{a}$ & $58,69 \mathrm{a}$ & $57,57 \mathrm{a}$ & $57,11 \mathrm{a}$ & $56,43 \mathrm{~b}$ \\
\hline
\end{tabular}

Médias seguidas de letras minúsculas distintas nas colunas diferem pelo teste Tukey $(\mathrm{p}<0,05)$

TABELA 8: PRINCÍPIOS NUTRITIVOS BRUTOS- PROP2/ PER2:

\begin{tabular}{lrrrrr}
\hline FATOR & \multicolumn{5}{c}{ FASES } \\
\cline { 2 - 6 } & \multicolumn{1}{c}{1} & \multicolumn{1}{c}{3} & \multicolumn{1}{c}{4} \\
\hline \% MS & $32,77 \mathrm{a}$ & $35,12 \mathrm{a}$ & $36,35 \mathrm{a}$ & $64,62 \mathrm{~b}$ & $86,57 \mathrm{c}$ \\
RHF & $0,78 \mathrm{a}$ & $0,86 \mathrm{ab}$ & $1,05 \mathrm{bc}$ & $1,09 \mathrm{c}$ & $1,11 \mathrm{c}$ \\
$\%$ PB & $20,07 \mathrm{a}$ & $19,02 \mathrm{a}$ & $17,45 \mathrm{~b}$ & $15,50 \mathrm{c}$ & $15,10 \mathrm{c}$ \\
$\%$ FB & $27,80 \mathrm{a}$ & $27,22 \mathrm{a}$ & $27,10 \mathrm{a}$ & $27,55 \mathrm{a}$ & $28,97 \mathrm{~b}$ \\
$\%$ EE & $1,73 \mathrm{a}$ & $1,74 \mathrm{a}$ & $1,59 \mathrm{a}$ & $1,36 \mathrm{a}$ & $1,60 \mathrm{a}$ \\
$\% \mathrm{MM}$ & $7,11 \mathrm{a}$ & $7,37 \mathrm{a}$ & $7,65 \mathrm{a}$ & $7,48 \mathrm{a}$ & $7,52 \mathrm{a}$ \\
$\%$ ENN & $44,31 \mathrm{a}$ & $44,63 \mathrm{a}$ & $46,19 \mathrm{a}$ & $46,88 \mathrm{a}$ & $47,11 \mathrm{a}$ \\
$\%$ NDT & $59,54 \mathrm{a}$ & $59,45 \mathrm{a}$ & $58,51 \mathrm{a}$ & $57,45 \mathrm{~b}$ & $57,73 \mathrm{~b}$ \\
\hline
\end{tabular}

Médias seguidas de letras minúsculas distintas nas colunas diferem pelo teste Tukey $(\mathrm{p}<0,05) *$ 
TABELA 9: PRINCÍPIOS NUTRITIVOS BRUTOS PROP 3/PER1 :

\begin{tabular}{lrrrrr}
\hline FATOR & \multicolumn{5}{c}{ FASES } \\
\cline { 2 - 6 } & \multicolumn{1}{c}{1} & \multicolumn{1}{c}{2} & \multicolumn{1}{c}{3} & \multicolumn{1}{c}{5} \\
\hline \% MS & $20,10 \mathrm{a}$ & $28,92 \mathrm{~b}$ & $42,47 \mathrm{c}$ & $62,97 \mathrm{~d}$ & $78,70 \mathrm{e}$ \\
RHF & $0,65 \mathrm{a}$ & $0,67 \mathrm{a}$ & $0,70 \mathrm{a}$ & $0,93 \mathrm{~b}$ & $1,33 \mathrm{c}$ \\
$\%$ PB & $18,97 \mathrm{a}$ & $17,70 \mathrm{~b}$ & $17,32 \mathrm{~b}$ & $17,55 \mathrm{~b}$ & $14,62 \mathrm{c}$ \\
$\%$ FB & $21,10 \mathrm{a}$ & $22,42 \mathrm{a}$ & $25,32 \mathrm{~b}$ & $26,00 \mathrm{~b}$ & $26,62 \mathrm{~b}$ \\
$\%$ EE & $1,32 \mathrm{a}$ & $1,49 \mathrm{a}$ & $1,76 \mathrm{a}$ & $1,43 \mathrm{a}$ & $1,49 \mathrm{a}$ \\
$\%$ MM & $9,13 \mathrm{a}$ & $8,74 \mathrm{a}$ & $8,74 \mathrm{a}$ & $8,54 \mathrm{a}$ & $8,73 \mathrm{a}$ \\
$\%$ ENN & $43,63 \mathrm{a}$ & $46,06 \mathrm{a}$ & $51,08 \mathrm{a}$ & $50,05 \mathrm{a}$ & $49,88 \mathrm{a}$ \\
$\% N D T$ & $60,18 \mathrm{a}$ & $59,38 \mathrm{a}$ & $57,98 \mathrm{~b}$ & $57,60 \mathrm{~b}$ & $57,09 \mathrm{~b}$
\end{tabular}

Tukey $(\mathrm{p}<0,05)$

TABELA 10: PRINCÍPIOS NUTRITIVOS BRUTOS- PROP3/PER2

\begin{tabular}{lrrrrr}
\hline FATOR & \multicolumn{5}{c}{ FASES } \\
\cline { 2 - 6 } & \multicolumn{1}{c}{1} & \multicolumn{1}{c}{3} & \multicolumn{1}{c}{4} & \multicolumn{1}{c}{5} \\
\hline \% MS & $28,82 \mathrm{a}$ & $33,65 \mathrm{a}$ & $32,27 \mathrm{a}$ & $62,42 \mathrm{~b}$ & $90,25 \mathrm{c}$ \\
RHF & $0,72 \mathrm{a}$ & $0,78 \mathrm{a}$ & $0,71 \mathrm{a}$ & $1,20 \mathrm{~b}$ & $1,47 \mathrm{c}$ \\
$\%$ PB & $17,07 \mathrm{a}$ & $17,15 \mathrm{a}$ & $16,77 \mathrm{a}$ & $16,55 \mathrm{a}$ & $15,15 \mathrm{~b}$ \\
$\%$ FB & $22,47 \mathrm{a}$ & $22,60 \mathrm{a}$ & $23,20 \mathrm{~b}$ & $23,02 \mathrm{~b}$ & $23,15 \mathrm{~b}$ \\
\%EE & $2,08 \mathrm{a}$ & $2,39 \mathrm{a}$ & $2,30 \mathrm{a}$ & $1,44 \mathrm{~b}$ & $1,49 \mathrm{~b}$ \\
$\%$ MM & $9,35 \mathrm{a}$ & $8,61 \mathrm{ab}$ & $8,87 \mathrm{ab}$ & $8,71 \mathrm{ab}$ & $8,23 \mathrm{~b}$ \\
$\%$ ENN & $49,04 \mathrm{a}$ & $49,62 \mathrm{a}$ & $49,38 \mathrm{a}$ & $49,98 \mathrm{a}$ & $50,97 \mathrm{a}$ \\
$\%$ NDT & $60,51 \mathrm{a}$ & $60,44 \mathrm{a}$ & $59,56 \mathrm{ab}$ & $58,66 \mathrm{~b}$ & $58,35 \mathrm{~b}$ \\
\hline
\end{tabular}

Médias seguidas de letras minúsculas distintas nas colunas diferem pelo teste Tukey $(\mathrm{p}<0,05)$

${ }^{*}$ Onde Prop $=$ propriedade, per $=$ período, $\mathrm{MS}=$ matéria seca, $\mathrm{RHF}=$ relação haste/folha, $\mathrm{FB}=$ fibra bruta, $\mathrm{EE}=$ extrato etéreo, $\mathrm{MM}=$ matéria Mineral, $\mathrm{ENN}=$ extrativo não nitrogenado, $\mathrm{NDT}=$ nutrientes digestiveis totais. 
TABELA 11- PERDAS DE PROTEÍNA BRUTA DA ALFAFA (\%) -PROP 1

\begin{tabular}{lcccccc}
\hline \multicolumn{3}{l}{ PERIODO 1 } & \multicolumn{5}{c}{ PERIODO 2 } \\
\hline FASES & RHF & PB\% & $\Delta$ PB $\%$ & RHF & PB $\%$ & $\Delta$ PB $\%$ \\
\hline 1 & 0,86 & 18,30 & - & 0,51 & 18,72 & - \\
2 & 0,79 & 17,4 & 4,91 & 0,88 & 17,12 & 8,55 \\
3 & 1,23 & 16,82 & 3,17 & 0,97 & 16,12 & 5,31 \\
4 & 1,59 & 16,22 & 3,28 & 1,09 & 15,70 & 2,24 \\
5 & 1,69 & 15,15 & 5,85 & 1,39 & 14,95 & 4,01 \\
PTPB & & & 17,21 & & & 20,14 \\
\hline
\end{tabular}

TABELA 12- PERDAS DE PROTEÍNA BRUTA (\%)- PROP 2

\begin{tabular}{lllllll}
\hline \multicolumn{3}{l}{ PERIODO 1 } & \multicolumn{5}{c}{ PERIODO 2 } \\
\hline FASES & RHF & PB\% & $\Delta$ PB\% & RHF & PB\% & $\Delta$ PB\% \\
\hline 1 & 0,74 & 19,35 & - & 0,78 & 19,07 & - \\
2 & 0,76 & 18,35 & 5,16 & 0,86 & 18,00 & 5,61 \\
3 & 1,60 & 16,50 & 9,56 & 1,05 & 16,85 & 6,03 \\
4 & 1,48 & 15,50 & 5,17 & 1,09 & 15,50 & 7,08 \\
5 & 1,41 & 15,25 & 1,29 & 1,11 & 15,10 & 2,09 \\
PTPB & & 21,18 & & & 20,81 & \\
\hline
\end{tabular}

ONDE:RHF= relação haste folha, $\% \mathrm{~PB}=$ proteína bruta, $\triangle \mathrm{PB} \%=$ variação na $\%$ de proteína bruta, $\triangle$ PTPB $\%=$ perda total de proteina bruta. 
TABELA 13 : \% PERDAS DE PROTEÍNA BRUTA - PROP 3

\begin{tabular}{|c|c|c|c|c|c|c|}
\hline FASES & PERI & & & $\overrightarrow{\text { PERI }}$ & & \\
\hline & RHF & $\% \mathrm{~PB}$ & $\Delta \mathrm{PB} \%$ & RHF & $\% \mathrm{~PB}$ & $\triangle \mathrm{PB} \%$ \\
\hline 1 & 0,59 & 18,97 & - & 0,72 & 18,47 & - \\
\hline 2 & 0,68 & 17,70 & 6,69 & 0,71 & 17,15 & 7,15 \\
\hline 3 & 0,70 & 17,55 & 0,79 & 0,78 & 16,77 & 2,06 \\
\hline 4 & 0,94 & 16,70 & 4,48 & 1,20 & 16,55 & 1,19 \\
\hline 5 & 1,34 & 15,80 & 4,74 & 1,47 & 15,70 & 4,60 \\
\hline$\triangle \mathrm{PTPB} \%$ & & & 16,71 & & & 14,99 \\
\hline
\end{tabular}

ONDE: $\mathrm{RHF}=$ relação haste folha, \% $\mathrm{PB}=$ proteína bruta, $\triangle \mathrm{PB} \%=$ variação na $\%$ de proteina bruta, $\triangle$ PTPB $\%=$ perda total de proteína bruta. 


\section{DISCUSSÃO:}

Observando-se as tabelas 20, 21 e 22 (apêndice), verifica-se que houve interação significativa para praticamente todas variáveis em cada propriedade nos períodos, fases $\mathrm{e}$ na interação de período e fases. Portanto, a análise de variância foi desmembrada por propriedade e período, e aplicado o teste Tukey para comparação de médias a um nível de significância de $0,05 \%$.

\section{MATÉRIA SECA (MS):}

Segundo RAYMOND et al (1978), 3/4 da umidade da forragem devem ser removidos no dia do corte. Na propriedade 1 , o período 1 verifica-se que praticamente $2 / 3$ da umidade da forragem foram removidos (tabela 5) no primeiro dia de campo, a forragem foi revolvida 2 vezes mais que o tradicional, e a secagem rápida pode ter sido favorecida pela baixa umidade relativa do ar no período $(53,2 \%)$, e pelo estágio de desenvolvimento, a forragem estando mais velha apresenta menor resistência cuticular à secagem (tabela 23, apêndice), secando mais rápido. Quando a forragem estava com $79,27 \%$ MS (fase 2) já poderia ser recolhida ao barracão, para secagem final à sombra, para ser enfardado, mas como não há um controle sobre o teor de MS, foi deixado a campo, favorecendo a perda de folhas, e consequentemente gerando um produto de menor qualidade.

No periodo 2, a secagem foi mais lenta. Observa-se na tabela 24 (apêndice) que a umidade relativa do ar nas fases 1 e 2 , no período $2(65,2 \%)$, foi maior que no período $1(53,2 \%)$, o que pode ter se relacionado com a perda de água mais lenta. Segundo CRUMP (1985) maior tempo de secagem para a forragem é requerido quanto maior for a umidade relativa do ar. A perda de umidade pela forragem foi mínima (tabela 6), nas fases 1,2 e 3 segundo se observa, quase atingindo fase final de secagem na fase 4 (MS=75,85\%), pois a partir de $45 \%$ de matéria seca, já é considerada fase final de secagem (NASH,1978).

A produção de matéria seca no Período 1 foi de $1.790 \mathrm{~kg} / \mathrm{ha} \mathrm{e}$ no período 2 foi de $1.070 \mathrm{~kg} / \mathrm{ha}$. A produção anual da Propriedade 1 foi de $7.419 \mathrm{~kg} / \mathrm{feno} / \mathrm{ha}$.ano (85\% 
de MS), correspondendo a $6.306 \mathrm{~kg} / \mathrm{MS} / \mathrm{ha}$.ano a que pode-se classificar como média/baixa, considerando que o potencial de produção de alfafa pode chegar a 22 ton/MS/ha.ano, e em relação à dados da literatura, em que as médias de produção de MS de alfafa Creoula vão de 13.79 ton/ha.ano, no trabalho de OLIVEIRA(1986) ou 12.98 ton MS/ha.ano, no trabalho de MONTEIRO (1996).

Na propriedade 2, a matéria seca no período 1 variou de $32,47 \%$ para $48,47 \%$ da fase 1 para fase 2 (tabela 7). A porcentagem de matéria seca para fase 3 foi de $87.50 \%$, já praticamente atingindo o ponto de feno, que poderia inclusive ter sido recolhido antes ao barracão, para secagem final com menores perdas.

De acordo com a tabela 26 (apêndice), a perda de água foi lenta, e pode ter sido influenciada pela porcentagem de URA (umidade relativa do ar), um pouco alta nas fases 1 e $2(66,2 \%)$. O teor de umidade do material no equilibrio é tanto menor quanto mais negativa for a atividade de água, e significa que o poder secativo do ar é maior, quanto mais negativa a atividade de água no ar. De acordo com a tabela 28 (apêndice), observase que no primeiro dia de secagem, o poder de secagem do ar foi menor que nos dias subsequentes ( -820$)$, sendo foi maior nas fases finais $(3,4$ e 5$),-729,-625$ e -629 , respectivamente.

No período 2, na fase 1, a matéria seca variou de $32.77 \%$ para $36.35 \%$ (tabela 8), a alfafa chegou na fase 4 com $64.62 \%$ de MS e na fase 5 com $86.57 \%$ de MS. Deve-se considerar também que a planta imatura demora mais a secar. De acordo com o tabela 28 (apêndice), o poder secativo do ar foi menor nas fases iniciais $(1,2$ e3) do que nas finais (4 e 5), o que deve ter facilitado mais a secagem.

A produção no periodo 1 foi de $439.5 \mathrm{~kg}$ de feno/ ha, e no período 2 foi de $776,9 \mathrm{~kg}$ feno/ha, correspondentes a aproximadamente $390 \mathrm{~kg} / \mathrm{MS}$.ha e $690 \mathrm{~kg} / \mathrm{MS}$.ha respectivamente. A produção anual de $5117 \mathrm{Kg}$ feno/ha.ano corresponde a, aproximadamente $4.093 \mathrm{Kg} \mathrm{MS} / \mathrm{ha}$.ano (feno com $85 \%$ umidade), que pode ser considerada baixa em relação ao potencial de produção de matéria seca da alfafa.

$\mathrm{Na}$ propriedade 3 a forragem só chegou a um teor de matéria seca seguro para estocagem com 2 dias de campo, o que pode desfavorecer a qualidade. Outro aspecto é o grau de maturidade da planta, a alfafa foi cortada bem no início da brotação basilar, ou 
seja, plantas mais jovens, e a sua maior resistência cuticular à secagem, pode ter influenciado a perda de água mais lenta, associada as condições climáticas, que podem não ter sido favoráveis, como no caso do período 1 , que a URA esteve alta $(64,2 \%)$, fator que teria dificultado a secagem.

De acordo com a observação da tabela 5 , no período 1 , a porcentagem de MS variou de 20,10 para $28,92 \%$ ( aumento de $43,8 \%$ ) e na fase 3 atingiu $42,47 \%$ entrando na fase final de secagem, chegando à fase 5 com $78,70 \%$ de MS. Na fase 3 pode ter ocorrido um favorecimento à secagem, pois a umidade relativa do ar decresceu de 64,2 para $58,7 \%$, e ainda houve um aumento na temperatura média ( 13,3 para $15,5^{\circ} \mathrm{C}$ ) nesta fase ( tabela 29 - apêndice). Como se observa na tabela 31 (apêndice), o poder secativo do ar foi maior nas fases finais $(3,4$ e 5$)$.

A produção de MS foi muito baixa no período 1 pois o alfafal estava se recuperando da geada de junho/94 ( dia 26/6/94). Nas outras propriedades em ocasião da geada a forragem já estava em ponto de corte, e na propriedade 3 ainda em fase de crescimento, que foi severamente prejudicado, com muita perda de matéria seca. A produção neste período foi $67,5 \mathrm{~kg}$ feno/ha, correspondendo a $53,3 \mathrm{~kg}$ de MS/ha corte. Pode-se considerar que a produção foi praticamente perdida.

A produção no período 2 teve uma recuperação, mas contudo ainda muito baixa, de $568.2 \mathrm{~kg}$ feno/ha correspondendo a aproximadamente $511.4 \mathrm{~kg} \mathrm{Ms} / \mathrm{ha}$. A produção total anual desta propriedade foi $5048.46 \mathrm{~kg} /$ feno/ha (média de $84.47 \%$ de MS), correspondendo a aproximadamente $4240.7 \mathrm{~kg}$ de $\mathrm{MS} / \mathrm{ha} / \mathrm{ano}$, Considerando-se o potencial de produção da forrageira, esta produção está muito baixa.

Pode-se observar nas tabelas 14 e 15; 16 e 17; 18 e 19 (apêndice) correspondentes às propriedades 1,2 e 3 respectivamente a porcentagem de matéria seca se correlacionou negativamente com a $\%$ de proteína bruta, e positivamente com a relação haste/folha. Pode-se inferir que o aumento da matéria seca, foi acompanhado por aumento na relação haste/folha, resultando em perda de proteína decorrente da perda de folhas .

A alfafa atingiu a matéria seca de estocagem ( $20-25 \%$ MS) a partir da Fase 3 ( 1 dia de campo) nas Propriedades 1 e 2 , o que significa que já poderia ser recolhida ao 
barracão para descanso e enfardamento, o que evita uma série de perdas devido à permanência da planta cortada por mais um dia no campo.

Como é tradição a forragem passar 2 dias cortada no campo e na prática não se utiliza um método eficaz para a medida da porcentagem de matéria seca a campo, a forragem em questão permaneceu por mais um dia a campo, embora estivesse apresentando níveis seguros de umidade para enfardamento já no primeiro dia. Com a forragem permanecendo mais do que o necessário a campo, a tendência é ocorrer uma maior perda de folhas, comprometendo o seu valor nutritivo, uma vez que as folhas se constituem na porção mais digestível da planta.

É um ponto para se trabalhar no processo, medindo o teor de MS corretamente, para se saber o momento em que a forragem pode ser recolhida ou enfardada com segurança, evitando perdas desnecessárias a nível de campo.

As baixas produções de matéria seca obtidas nas propriedades 1, 2 e 3: 7.418 $\mathrm{kg} /$ feno/ha/ano $6300 \mathrm{~kg} / \mathrm{MS} / \mathrm{ha}$.ano), $5.117 \mathrm{~kg} /$ feno/ha.no (4400 kg/MS/ha.no) e 5048 $\mathrm{kg} /$ feno/ha/ano (4038 $\mathrm{kg} / \mathrm{MS} / \mathrm{ha}$.ano) podem ser decorrentes da falta de implantação adequada da cultura, preparação inadequada do solo segundo as recomendações, falta de adubação de cobertura e controle adequado de pragas e doenças.

\section{RELAÇÃO HASTE/FOLHA (RHF):}

Na propriedade 1, período 1, a perda de folhas passa a ocorrer da fase 2 para a fase 3 e da 3 para a 4, ou seja, a 1 e 2 dias de permanência a campo (tabela 5), sendo maior no segundo dia de campo. Relacionando-se com a matéria seca, na fase 3 ( 1 dia de campo) quando a matéria seca já havia atingido a $85,75 \%$ de MS, pode-se considerar que a forragem já estava pronta para o enfardamento, porém permaneceu por mais 1 dia no campo, e com o revolvimento houve uma maior perda de folhas, sendo refletido na relação haste/folha, ocorrendo uma maior perda de folhas entre as fases 3 e 4 (tabela 5).

No período 2 a RHF aumentou da fase 1 para 2, e da fase 2 para 3, neste caso a porcentagem de matéria seca na fase 3 foi de $41,42 \%$, ainda não havia sido atingido o ponto de feno (tabela 6). Verifica-se que nos periodos 1 e 2 a perda de folhas ocorreu das fases 2 para 3 , a partir do segundo dia de campo.. Poder-se-ia atuar neste ponto, por 
exemplo, mantendo a forragem somente um dia a campo se possível, e conduzi-la após o primeiro dia para a secagem final à sombra, o que provavelmente resultaria em menor perda de folhas.

Na propriedade 2 verificou-se no periodo 1 um aumento significativo $(p<0,05)$ na relação haste/folha (tabela 7), comprovando que houve perda de folhas também na propriedade 2 , especialmente da fase 2 para a fase 3 . A porcentagem de matéria seca subiu rapidamente, e com 1 dia de campo atingiu a $87,50 \%$ no periodo 1 . A maior relação haste/folha atingida na fase 3 está relacionada com a perda ocorrida de folhas que também foi maior. $\mathrm{O}$ aumento da matéria seca e o manuseio favoreceram as perdas, considerando-se que a partir desta porcentagem de matéria seca $(87,50 \%)$, a alfafa já pode ser enfardada.

Verificou-se no período 2 um aumento significativo $(\mathrm{P}<0,05)$ na relação haste/folha (tabela 8), mas com valores menores do que no período 1 . Deve-se levar em conta que a porcentagem de matéria seca no período 2 aumentou mais lentamente.

$\mathrm{Na}$ propriedade 3, as variações na relação haste/folha no periodo 1 foram significativas ( $p<0.05$ ), (tabela 9), não variando muito nas fases 2 e $3 \quad(0,59$ e 0,67), mas aumentando significativamente nas fases 4 e $5(0,93$ e 1,33). O cuidado durante $o$ processamento e o enfardamento é importante para reduzir a perda de folhas. Também observa-se que no período 1 quando a MS atingiu $78,70 \%$, a relação haste/folha foi a mais alta, e consequentemente as perdas de folhas também aumentaram, no período 2 as perdas foram ainda maiores, devido ao grande aumento no teor de MS, que atingiu a $90,25 \%$. A variação no período 2 não foi significativa, nas fases 1,2 e $3(0,72 ; 0,78$ e 0,71 ) (tabela 10), mas aumentou nas fases 3 e $4(1,20$ e 1,47), e se relaciona com o aumento da porcentagem de MS na forragem

A relação haste/folha sofreu um aumento significativo $(P<0.05)$, em especial nas fases 3 e 4, nas 3 propriedades, o que significa que em relação à perda de folhas, corresponde um aumento proporcional no porcentagem de hastes, e as perdas estão sendo maiores nas fases 3 e 4 ( 2 para 3 dias de campo).

Pela literatura, os teores médios de proteína nas folhas são $50 \%$ maiores que nos caules (HONDA \& HONDA,1990). A contribuição para a maior parte do valor de 
proteina da planta vem das folhas, e a perda de folhas deve ser evitada, pois a perda de qualidade do produto deve ser a menor possível. Como se observa nestas propriedades que o fator mais crítico é a forragem ficar cortada mais de 1 dia no campo, deve-se procurar interferir de forma que a forragem permaneça se possivel 1 só dia a campo, sendo recolhida após esse período.

A relação haste/folha (RHF) está correlacionada nas 3 propriedades com a matéria seca, ou seja, conforme aumenta a MS aumenta a RHF, e com a proteína bruta (PB); se a RHF aumenta, a PB tende a diminuir. Então podemos dizer que o aumento da relação haste/folha pode ser um bom indicativo das perdas de PB que ocorrem em cada fase.

\section{PROTEÍNA BRUTA (PB):}

A proteina é um dos fatores mais considerados quando se leva em conta a avaliação do valor nutritivo da forragem. As folhas da alfafa tem um teor protéico maior que os caules, e correspondem à porção mais digestível da planta. A perda de folhas decorrente do processo de secagem vai levar a uma diminuição do teor protéico, em relação à planta original.

Observa-se uma diminuição significativa $(p<0,05)$ nos teores de $\mathrm{PB}$ nas fases de 1 a 5 nas 3 propriedades, estando esta perda relacionada com o aumento na relação haste/folha, significa que está relacionada com a perda de folhas.

A perda de proteína está correlacionada com a relação haste/folha como já verificaram BASSOLS \& PAIM (1978): aumentando-se a relação haste/folha a proteína bruta diminui.

Na propriedade 1, nos períodos 1 e 2 pode-se observar uma diminuição gradual no teor de $\mathrm{PB}$, o qual acompanha a relação haste/folha. Ou seja, o aumento na proporção haste/folha significa a perda de folhas e consequentemente do teor protéico. Não há diferença significativa nas fases 1 e 2 (período 1), mas a perda passa ocorrer a partir da fase 3 (tabela 5), o que coincide com o aumento na relação haste/folha. A perda de proteína bruta nos períodos 1 e 2 foi da ordem de $17,21 \%$ e $20,14 \%$ respectivamente (tabela 11). 
Na propriedade 2, de acordo com as tabelas 7 e 8 observou-se um decréscimo na porcentagem de proteína a partir da fase 3 coincidindo com o aumento no valor da relação haste/folha (maior perda de folhas). De acordo com a tabela 12, a perda em relação à porcentagem inicial de proteína bruta foi de $21,18 \%$ e $20,81 \%$ para os períodos 1 e 2 respectivamente (tabela 12). No período 2, a perda de PB vai se acentuar a partir nas fases 4 e 5 , o que é esperado uma vez que os valores de relação $\mathrm{H} / \mathrm{F}$ estarão se acentuando neste período, estarão se perdendo folhas, o que justificaria a perda de proteína.

Na propriedade 3, no período 1 houve um decréscimo da fase 1 para a fase 2, o que não deve ser devido à perda de folhas, e sim a perdas respiratórias, pois a planta não teve um processo de secagem rápida e não houve diferença significativa na relação haste/folha, portanto não devem ter ocorrido perdas de folhas. Nas fases 2,3 e 4 não houve diferença significativa entre os valores, mas também não se observaram acréscimos na relação haste/folha nas fases 2 e 3 (tabela 9). A diminuição no teor de proteína coincidiu com o aumento da relação haste/folha na fase 5 , ou seja, a fase de maior perda de folhas.

No periodo 2 foram observadas diferenças significativas entre as fases de 1 a 4 , praticamente coincidindo com os aumentos ocorridos na relação haste/folha. Houve uma diminuição significativa na fase $5(\mathrm{p}<0,05)$, coincidindo com o aumento significativo da RHF ( relação haste/folha). As porcentagens de perda de PB nos períodos 1 e 2 foram de $16,71 \%$ e $14,99 \%$ respectivamente (tabela 13 ).

Os níveis de PB tendem a ser maiores nas forragens verdes e há uma diminuição na porcentagem de $\mathrm{PB}$ após corte, da fase 1 para a fase 2 , que pode ser relacionada com as perdas respiratórias. A diminuição nos níveis de $\mathrm{PB}$ se relaciona com a perda de folhas (tabelas 11, 12 e 13). É preciso se interferir no processo de fenação de modo a evitar a perda de folhas, especialmente se a forragem ficar mais de um dia cortada no campo.

Nas tabelas 14 e $15 ; 16$ e 17; 18 e 19 (apêndice), relacionadas com as propriedades 1,2 e 3 respectivamente, observa-se que as perdas do teor de proteina se correlacionaram negativamente com o aumento da relação haste/folha, ou seja, com a 
perda de folhas, e com o aumento da porcentagem de MS, diminuiu a porcentagem de PB. Observa-se ainda nas propriedades 1,2 , e 3 (período 2) que houve uma correlação positiva entre a porcentagem PB e NDT, ou seja, a tendência com a diminuição da PB é uma diminuição dos niveis de NDT. E ainda observou-se uma correlação negativa da porcentagem de PB com ENN, ou seja conforme diminui o teor proteíco a tendência seria aumentar o extrativo não nitrogenado.

Os teores médios de proteína contidos nas folhas são no mínimo $50 \%$ maiores do que nos caules (HONDA \& HONDA, 1990), e a contribuição para a produção de PB originária das folhas foi de $71 \%$ em um trabalho conduzido por OLIVEIRA et al (1993). Pode-se concluir do descrito acima que a perda de folhas deve ser evitada e/ou minimizada, para que o produto final tenha um melhor valor nutritivo.

Um nível de perdas de matéria seca aceitável seria de 2 a $5 \%$, (BUCKMASTER \& ROTZ, 1986), ou de 5 a $10 \%$ (WOLF \& CARSON, 1973), atribuídas à respiração e atividade microbiana nas fases iniciais ( 1 e 2 ), e após a fase 2 o manuseio deve ser cuidadoso para evitar a perda de folhas, evitando assim a diminuição do teor de PB.

Observa-se também que o valor encontrado para as porcentagens de PB estão relativamente menores do que os encontrados na literatura, para feno de alfafa crioula.

\section{FIBRA BRUTA (FB)}

Observa-se um aumento no teor da fibra nas fases 1 a 5. O aumento da fibra bruta se relacionou inversamente com a $\mathrm{PB}$ e diretamente com a relação haste/folha. Segundo a literatura a tendência é de aumentar o teor de FB com o processo de secagem e com a maturidade da planta. Essas tendências ocorreram no experimento. Verificou-se que o teor de fibra foi aumentando gradativamente com o processo de secagem e com o grau de maturidade da planta .

$\mathrm{Na}$ propriedade 1 , periodo 1 (tabela 5) observa-se aumento significativo na porcentagem de fibra correspondente a $17,36 \%$, ocorrendo a partir da fase 3 como acontece com a relação haste/folha que aumenta a partir da fase 3, e a porcentagem de fibra bruta $(\mathrm{FB})$ apresenta então uma relação inversa à porcentagem de proteína bruta (PB) que diminui justamente neste período. O valor encontrado neste período para a 
porcentagem de $\mathrm{FB}$, no caso da forragem fresca $(22,92 \%)$ está acima do valor estimado por ANDRIGUETTO et al (1992) que é de 20,37\%, mas está na média ou até abaixo em relação às porcentagens de fibra bruta de $25,88 \%$ (feno de Lajes-Sc) e 37,03 \% (feno comercial) citadas por NUERNBERG et al (1990), e 28.0\% citado por MACDOWELL et al (1974).

No período 2, também observou-se um aumento na porcentagem de fibra bruta (tabela 6), que foi de $19,35 \%$. O aumento ocorreu a partir da fase 4 , neste periodo também observou-se um aumento na relação haste/folha. A porcentagem de FB para a forragem verde está de acordo com a encontrada na literatura, ANDRIGUETTO et al (1992). A porcentagem de fibra nas demais fases, está dentro do esperado, pois acompanharam o aumento dos valores da relação haste/folha.

Na propriedade 2 houve também um aumento nos teores de FB nos períodos $1 \mathrm{e}$ 2 (tabelas 7 e 8). Fato que pode estar relacionado com o estado fisiológico da planta ao corte, que foi estádio de brotação basilar avançada. Os teores de FB encontrados correspondem aos valores da literatura. A planta apresenta um maior grau de maturidade, e uma porcentagem de FB maior que a planta em estádios mais jovens, como foi o caso das outras propriedades e períodos.

$\mathrm{Na}$ propriedade 3 , observou-se, no período 1 , um aumento significativo na porcentagem de fibra bruta a partir da fase 3 (tabela 9), perfazendo um aumento total de $26.16 \%$. O teor de FB encontrado no feno do período 1 foi de $26.32 \%$.Deve-se considerar que a perda de folhas leva a um aumento proporcional na quantidade de hastes, e pode-se dizer que colabora para o aumento no teor de fibra.

No período 2 houve um aumento nos teores de FB, como se observa na tabela 10. Os teores de fibra bruta estão menores que os encontrados para feno comercial e feno de Lages/SC (NUERNBERG et al,1990).

O teor de FB está negativamente correlacionado com o teor de ENN e NDT (tabelas 18 e 19), pois o aumento da fibra, pode estar relacionado a diminuição do conteúdo celular e consequentemente do ENN, e também do teor de NDT.

Observando-se as tabelas 14 e 15;16 e 17; 18 e 19 (apêndice), correspondentes as propriedades 1,2 e 3 respectivamente verifica-se que o aumento da $\%$ de fibra se 
correlaciona negativamente com o extrativo não nitrogenado e nutrientes digestíveis totais. Com a perda de folhas, resulta o aumento da proporção de hastes, consequentemente o teor de fibra, e com isso o conteúdo celular, no caso representado pelo ENN, tenderia a diminuir, assim como o NDT.

\section{EXTRATO ETÉREO (EE)}

Os valores de extrato etéreo para as fases 1 a 5 , podem ser considerados dentro do previsto, praticamente não houve alteração nos valores de EE, desde a planta verde até feno. Nas propriedades em que a planta foi cortada com cerca de $50 \%$ de brotação basilar, mais amadurecida, neste ponto de corte, é de se esperar que os níveis de extrato etéreo sejam mais baixos que em plantas mais jovens, pois estas tem um teor de extrato etéreo maior neste estádio, apresentando também maior resistência cuticular, fato este que dificulta a secagem, não é de se esperar muita variação, pois considera-se que a porcentagem de EE, não é muito expressiva em termos de alfafa, pois é originária da cutícula, que é consituída basicamente de ceras solúveis e grandes cadeias de ácidos graxos esterificados, que se apresenta mais espessa em plantas mais jovens, e neste tipo de plantas pode haver maior variação, até diminuição que nas plantas mais maduras.

$\mathrm{Na}$ propriedadel observa-se nos períodos $1 \mathrm{e} 2$, que praticamente não houve alteração nos valores de extrato etéreo (tabelas 5 e 6), desde a planta antes do corte até o ponto de feno. Os valores obtidos são comparáveis aos da literatura. Os valores para o estágio vegetativo estão mais baixos que os citados por ANDRIGUETTO et al (1992), mas próximos aos citados por MACDOWELL et al (1974).

$\mathrm{Na}$ propriedade 2 observa-se nos períodos 1 e 2 , que não houve alterações significativas no teor de extrato etéreo do estádio verde, para as fases de secagem, até feno (tabelas 7 e 8). Tendo a planta sido cortada num estádio mais avançado, com mais que $50 \%$ de brotação basilar, é de se esperar que os níveis de extrato etéreo estejam mais baixos do que se a forragem estivesse em um estágio vegetativo mais jovem, como já foi exposto anteriormente.

$\mathrm{Na}$ propriedade 3 observa-se que no período 1 (tabela 9) não ocorreram diferenças significativas nos valores de EE. No período 2, uma diminuição nas 
porcentagens de extrato etéreo, desde a planta verde até fenada (tabela 10). A planta foi cortada com menos de $20 \%$ de brotação basilar, sendo uma planta mais jovem deve-se esperar valores um pouco mais altos no extrato etéreo que nas propriedades e períodos anteriores. No período 2 observa-se níveis iniciais (verde) mais altos de extrato etéreo, pois a planta foi cortada em um estagio mais jovem que as anteriores. A diminuição nos níveis de $\mathrm{EE}$ foi da ordem de $28,36 \%$.

Observa-se uma correlação entre a porcentagem de EE e os valores de NDT (tabelas 14 e $15 ; 18$ e 19), correspondentes às propriedades 1 e 3 . Na propriedade 1 houve uma correlação da porcentagem de EE com RHF (período1) e MS (período 2), ou seja conforme aumenta a MS e RHF, aumenta o EE .

\section{MATÉRIA MINERAL: (MM)}

Observa-se nas leguminosas que elas tem maior quantidade de nitrogênio, fósforo, potássio, e cálcio que as gramíneas segundo HONDA \& HONDA (1990). Observou-se que não houve alteração dos valores de matéria mineral da planta verde, para as fases de secagem até feno.

Durante o processo de secagem da forragem há perda de água, conteúdo celular, carboidratos, entre outros, devido à respiração celular e proteínas através da perda de folhas, e a matéria mineral praticamente não é alterada.

Na propriedade 1, observa-se nos períodos 1 e 2 que não houve diferenças significativas nas fases (tabelas 5 e 6). As porcentagens de MM encontradas no feno, de $9,09 \%$ e $8,42 \%$, para os períodos 1 e 2 é similar à encontrada na literatura (ANDRIGUETTO et al, 1992).

Na propriedade 2, não ocorreram diferenças significativas, entre as cinco fases dos períodos 1 e 2 (tabelas 7 e 8). As porcentagens de MM encontradas no feno, que foram iguais $(7,52 \%)$, são similares às encontradas na literatura (ANDRIGUETTO et al, 1992).

$\mathrm{Na}$ propriedade 3 , observou-se no período 1 que não houve diferença significativa na porcentagem de MM (tabela 9), e no período 2 houve uma pequena 
diminuição. As porcentagens de $\mathrm{MM}$ encontradas no feno, (8,73 e $8,23 \%)$, para os períodos 1 e 2, estão dentro da média da literatura (ANDRIGUETTO et al, 1992).

\section{EXTRATIVOS NÃO NITROGENADOS: (ENN)}

Na propriedade 1, observou-se nos períodos 1 e 2, que praticamente não houve diferenças significativas no teor de extrativos não nitrogenados (ENN), (tabelas 5 e 6).

Na propriedade 2 verificou-se no período 1, que os valores de extrativo não nitrogenado (ENN) não tiveram variações significativas. Segundo observa-se na tabela 7 , mas como também não houve variações em outros princípios nutritivos, que através de cálculo dão origem a ENN, é até esperado que este não varie também. A porcentagem de ENN do feno do período 1 foi de 43,55\%.

Verificou-se no período 2, que não houve alterações significativas nos valores de ENN, nas fases 4 e 5 (tabela 8). A porcentagem de ENN no período foi de $37,88 \%$ para o feno.

Na propriedade 3 observou-se nos períodos 1 e 2, que não houve alteração significativa nos níveis de ENN, e praticamente não houve grandes alteração nos outros princípios nutritivos, exceto proteína bruta (tabelas 9 e 10).

$\mathrm{O}$ ENN se correlaciona negativamente com as porcentagens de FB e PB, ou seja, ele será maior, conforme os outros dois diminuirem, e com as porcentagens de RHF, MM e NDT, é esperado que se correlacione com todos, pois é resultado da subtração de 100 dos outros princípios exceto NDT. (tabelas 14 e 15;16 e 17; 18 e 19-apêndice).

\section{NUTRIENTES DIGESTIVEIS TOTAIS: (NDT)}

O que se observa na literatura é uma tendência à diminuição nos teores de NDT, da planta verde, para outras formas de apresentação como desidratada, no início ou final da floração e na forma de feno, e esta diminuição está associada com as perdas em cada fase durante o processo de secagem.

Na propriedade 1, observa-se que nos períodos 1 e 2 , uma tendência a diminuição nos teores de NDT (tabelas 5 e 6), da planta verde nas diferentes fases até chegar a feno , o que se pode associar com as perdas ocorridas: perdas com respiração da planta e dos 
microorganismos presentes, perdas com o processo da fenação em si, especialmente pela perda de folhas.

Na propriedade 2, nos períodos 1 e 2 observa-se uma diminuição nos teores de NDT (tabelas 7 e 8). Os valores de NDT encontrados para os fenos dos períodos 1 e 2 foram $57.43 \%$ e $57.73 \%$ respectivamente.

Na propriedade 3 observou-se uma diminuição no teores de NDT, nos dois períodos, como nos períodos anteriores, pelos motivos descritos anteriormente.De acordo com os níveis de NDT encontrados para o fenos dos períodos 1 e 2 , eles podem ser classificados como fenos de qualidade média. E observou-se que as 3 propriedades apresentaram fenos de características similares.

Observa-se nas tabelas 14 e 15; 16 e 17; 18 e 19 (apêndice) que o NDT se relaciona negativamente com a $\mathrm{FB}$, ou seja conforme aumenta a fibra diminui NDT, e positivamente com a proteína o extrato etéreo. Ou seja, com o aumento da MS e RHF, há perda de folhas, de PB e consequentemente diminui o NDT em função das perdas globais. 


\section{CONCLUSÕES}

O número de dias de secagem do feno a campo é excessivo, sendo que a forragem permanece além do que seria necessário no campo, levando a uma maior perda de folhas e consequentemente à perda de $\mathrm{PB}$ e decréscimo na qualidade do feno. $\mathrm{O}$ ideal seria deixar somente um dia a campo, e transportar ao barracão a partir do segundo dia para secagem final à sombra.

Tendo em vista a alta correspondência entre a RHF e a qualidade da forragem, o uso desta relação mostrou-se útil não só para avaliar o feno obtido como as várias etapas do processo de fenação. Portanto a relação haste/folha (RHF) pode ser um bom parâmetro para identificar e avaliar as perdas que estão ocorrendo em cada fase.

Os valores de MS, RHF e PB aumentaram, enquanto que os valores de PB e NDT diminuiram, e os valores de EE, ENN e MM não sofreram alterações significativas no decorrer do processo de secagem. 


\section{REFERÊNCIAS BIBLIOGRÁFICAS:}

ALLEN, M.S.; O 'NEIL, K.A.; DADO, R.G.; et al. Variation in fiber content and fiber digestibility of alfalfa and corn forages. East Lansing: Michigan State University, Department of Animal Science, 1992. 25p.

ANDRIGUETTO, J.M.; PERLY, L.; MINARDI, I. et al. Normas e padrões de nutrição e alimentação animal. São Paulo: Nutrição Editora, 1992. 146 p.

ASSOCIATION OF OFFICIAL AGRICULTURAL CHEMISTS. Official methods of analysis. Washington, $1970.1015 \mathrm{p}$.

ARAÚJO FILHO, S.A.; GADELHA, S.A; PEREIRA, R.M.A. et al. Competição entre 11 variedades de alfafa (Medicago sativa $L$.). Revista da Sociedade Brasileira de Zootecnia, v. 1, p. 77-88, 1972.

BASSOLS, P.A.; PAIM, N.R. Estudo comparativo de cultivares de alfafa (Medicago sativa L.) introduzidas no Rio Grande do Sul. Anuário Técnico do IPZFO, v. 5, p.349-416,1978.

BOLTON, J.L. Alfalfa: botany, cultivation and utilization. London : World Crop Books, 1962. 474p.

BOLTON, J.L.; GOPLEN, B.P.; BAEZINGER, H. World distribuition and historical developments. In: HANSON,C.H. Alfalfa: science and technology. Madison: American Society of Agronomy. 1972. p. 1-34.

BOON LONG, T.S. Transpiration is influenced by osmotic concentration and cell permeability. American Journal of Botany, v.28, p. 333-343, 1941.

BUCKMASTER, D.R.; HEINRICHS, A. J. Losses and quality during harvest and storage of preservative-treated alfalfa hay of varying moisture content. Transactions of the ASAE, v. 36, n.2, p. 349-353, 1993. 
BUCKMASTER, D.R.; ROTZ, C.A.; MERTENS, D.R. A model of alfalfa hay storage. Transactions of the ASAE, v. 32, n.1, p. 30-36, 1989.

BURTON, J.C. Nodulation and symbiotic nitrogen fixation. In: HANSON C.H.

Alfalfa: science and technology. Madison: American Society of Agronomy, 1972 p. 229-244.

CARTER, W.R.B. A review of nutrient losses and efficiency of conserving herbage as a silage, barn-dried and field cured hay. Journal of the British Grassland Society, v. 15, p. $220-230,1960$.

CIOTTI, A.; CAVALLERO, A. Haymaking losses in cocksfoot-lucerne mixture in relation to conditioning and degree of drying at harvest. In: THOMAS C. (Ed.) Forage conservation in the 80's. Hurley: British Grassland Society, 1980. p.214220. (Occasional Symposium, 11).

CLARK, B.J.; MACDONALD, P. The drying pattern of grass swaths in the field Journal of the British Grassland Society, v.32, n.2, p. 77-81, 1977.

COLLINS, M. Wetting effects on the yield and quality of legume hay. Agronomy Journal, v.77, p. 936-941, 1985.

COLLINS, M. Hay curing and water soaking: Effects on composition and digestion of alfalfa leaf and stem components. Crop Science, v. 31, p. 219-223, 1991.

COLUMELLA, L.J.M. On agriculture. London. Harvard University Press, 1941. $870 \mathrm{p}$.

CRUMP, S.V. Potassium carbonate and forage drying. Edmonton, 1985. 96p. Dissertation (M.Sc.)- Alberta University. 
DERNEDEE, W. Treatments to increase the drying rate of cut forage. In: THOMAS, C. (Ed.). Forage conservation in the 80's. Hurley: British Grassland Society, 1980. p. 61-66. (Ocasional Symposium, 11).

FELDMAN, M.; LIEVERS, K.W. Effect of harvesting equipament and methods on hay and forage quantity and quality. In: INTERNATIONAL GRAIN AND FORAGE CONFERENCE, 1., Ames, 1977. Proceedings. Ames: Iowa State University, 1978. p. 323-326.

FONTES, P.C.R.; MARTINS, C.E.; CÓSER, A.C.; VILELA, D. Produção e níveis de nutrientes em alfafa (Medicago sativa L.) no primeiro ano de cultivo, na zona da mata de MG. Revista da Sociedade Brasileira de Zootecnia, v.22, n.2, p. 205211, 1993.

FRIESEN,O. Evaluation of hay and forage harvesting methods. In: INTERNATIONAL GRAIN AND FORAGE CONFERENCE, 1., Ames, 1977. Proceedings. Ames: Iowa State University, 1978. p. 317-322.

GOERING, H.R.; VAN SOEST, P.J. Forage fiber analysis: apparatus reagents, procedures and some applications. Washington: USDA, Agricultural Research Service, 1970. $379 \mathrm{p}$.

GONZALEZ, E; GUILLEN, R.D.; TESORO, T. Algumas observaciones sobre la produción y valor nutritivo de la alfalfa (Medicago sativa $L$.) en condiciones tropicales. AgronomiaTropical, v. 20, p. 397-404, 1970.

GONZALEZ, E.; PARRA, R.; COMBELLAS, J. Composicion y valor nutritivo de los forrajes producidos en el tropico - 3. Consumo y digestibilidad de la materia seca. AgronomiaTropical, v.22, p. 613-621, 1972.

HANSON, C.H. Alfalfa science and technology. Madison: American Society of Agronomy, 1972. $812 \mathrm{p}$. 
HANSON, C.H. Alfalfa and alfalfa improvement. Madison: American Society of Agronomy, 1988. $1084 \mathrm{p}$.

HARRIS, C.E.; TULLBERG, J.N. Pathways of water loss from legumes and grasses cut for conservation. Grass and Forage Science, v.37, p. 151-157, 1980.

HART, R.H.; BURTON, G.W. Curing coastal bermudagrass hay: Effects of weather, yeld, and quality of fresh herbage on drying rate, yeld, and quality of cured hay. Agronomy Journal, v.59, p. 367-371, July/Aug. 1967.

HOGLUND, D.C.R. Comparative losses and feeding values of alfalfa and corn silage crops when harvested at different moisture levels and stored in gastight and convencional tower silos: An apprisal of research results. Michigan : Agronomy Ec. Publisher, 1964. 147 p.

HONDA, C.S. ; HONDA, A.M. Cultura da alfafa. Cambará: Ed.Iara Artes Gráficas, 1990. $247 \mathrm{p}$.

JACQUES, A.V.A. Manejo da espécies do gênero Medicago. In: SIMPÓSIO DE MANEJO DE PASTAGENS, 9., Piracicaba, 1988. Piracicaba: FEALQ, 1988. p. 269-283.

JACQUES, A.V.A.; STAMMEL, J.G; RIBOLDI, J. Efeito do estádio de crescimento e altura de corte sobre a matéria seca, p.b. e minerais da alfafa crioula (Medicago sativa L.). In: REUNIÃO DA SOCIEDADE BRASILEIRA DE ZOOTECNIA. 19, Piracicaba, 1982. Anais. Campinas: S B Z, 1982. p. 435-436.

JONES, L.; HARRIS, C.E. Plant and swath limits to drying. In: THOMAS,C. (Ed.). Forage conservation in the 80's. Hurley: British Grassland Society, 1980. p. 5360. (Occasional symposium, 11). 
JUNG, G.A.; LARSON, K.L. Cold drought, and heat tolerance. In: HANSON,C.H. Alfalfa: science and technology. Madison: American Society of Agronomy, 1972. p.185-209.

KALU, B.A.; FICK, G.W. Quantifying morfhological development of alfalfa for studies herbage quality. Crop Science, v. 21, p.267-271, 1981.

KALU, B.A.; FICK, G. W. Morphological stage of development as a predictor of alfalfa herbage quality. Crop Science, v.23, p.1167-1172, 1983.

KEPLIN, L.A.S.; SANTOS, I.R. Princípios e práticas para o estabelecimento e manejo da cultura: Suplemento do Jornal da Dirat, n.84, p.17-23, 1991.

KEARL,L.C. Nutrients Requirements of ruminants in developing countries.

Logan: Utah State University. Internationational Feedstuffs Institute. 1982. 386 p.

KLINKOWSKI, M. Herbage plants. Wales: Imperial Bureau of Plant Genetics. 1933. $46 \mathrm{p}$.

KLINNER, W. E. Design and performance characteristics of ans experimental crop conditioning system for difficult climates. Journal of Agricultural Engineering Research, v.20, p. 149-165, 1975.

KLINNER, W.E. ; SHEPPERSON, G. The State of haymaking technology- a review. Journal of the British Grassland Society, v.30, n.3, p. 259-266, 1975.

KNAPP, W.R.; HOLT, D.A.; LECHTENBERG, V.L. Propionic acid as a hay preservative. Agronomy Journal , v.68, p. 120-123, 1976.

KOEGEL, P.G. ; STRAUB,R.J.; WALGENBAH, R.P. Quantification of mechanical losses in forage harvesting and storage methods. Journal of Dairy Science, v.67, p. $2475-2480,1985$. 
LARSEN, W.E.; RIDER, A.R. Mechanization of forage harvesting and handling. In: HEATH,M.E; BARNES,R.F.; METCALFE,D.S. (Ed.) Forages: the science of grassland agriculture. Ames: Iowa State University Press, 1985. p. 452-459.

LECHTENBER,V.L. Preserving and increasing quality in harvested forages. In: FORAGE AND GRASSLAND CONFERENCE, 27, Raleigh. 1978, Raleigh: American Forage and Grassland Council, 1978. p. 85-91.

MAC DONALD, A.D.; CLARK, E.A. Water and quality loss during field drying of hay. Advances in Agronomy, v.41, p. 407-437, 1989.

MARTIN, N.P. Alfalfa: handbook of energy utilization in agriculture. Florida: CRC Press, 1980. $275 \mathrm{p}$.

MC DOWELL, L.R.; CONRAD, J.H.;THOMAS, J.E. et al . Latin American tables of feed composicion. Gainsville: University of Florida, 1974. 290p.

MEIDNER, $\mathrm{H}$. Cuticular conductance and the humidity response of stomata. Journal of Experimental Botany, v.37, n.177, p. 517-525, 1986.

MONTEIRO, A.L.G. Produção e distribuição de matéria seca, composição química e potencial para ensilagem de cultivares de alfafa (Medicago sativa L.). Botucatu, 1996. 49 p. Tese (Doutorado) - Faculdade de Medicina Veterinária e Zootecnia, Universidade Estadual Paulista Julio de Mesquita Filho.

MORRIS, R.M. The rate of water loss from grass samples during hay type conservation. Journal of the British Grassland Society, v.27, n.2, p. 99-105, 1972.

MURDOCK, J.C. Grass: its production and utilization. Oxford: HOLMES, W. (Ed.), 1980. p. 175-215. 
NASH, M.J. Crop conservation and storage in cool temperature climates: the imediate future. Journal of the Royal Agricultural Society of England, v.139, p.64-73, 1978.

NUERNBERG, N.J. Técnicas de produção de alfafa. In: CONGRESSO BRASILEIRO DE PASTAGENS, 8., Piracicaba, 1986. Anais. Piracicaba: FEALQ, 1986. p. 145-160.

NUERNBERG, N.J.; MILAN, P.A.; SILVEIRA, C.A.M.. Manual de produção de alfafa. Florianópolis: Empasc, 1990. 102 p.

OLIVEIRA, P.R.D. Avaliação da produção e da qualidade de cultivares de alfafa (Medicago sativa L.). Piracicaba, 1986. 86 p. Dissertação (Mestrado). Escola Superior de Agricultura "Luiz de Queiroz", Universidade de São Paulo.

OLIVEIRA, P.R.D.; PAIM, N.R.; CZERMAINSKI, A.B.C. Seleção para rendimento e qualidade da forragem em alfafa crioula. Pesquisa Agropecuária Brasileira, v.28, n.9, p.1039-1044, 1993.

PATIL, R.T.; SOKHANSANJ, S.; ARINZE, E.A. et al . Methods of expediting drying rates of chopped alfalfa. Transactions of the ASAE, v. 36, n.6, p. 1799-1803, 1993.

RANDO, E.M. Desenvolvimento da alfafa (Medicago sativa L.) em diferentes níveis de pH, potássio e enxofre no solo. Piracicaba, 1992. Tese (Doutorado). Escola Superior de Agricultura "Luiz de Queiroz", Universidade de São Paulo.

RAYMOND, F.; SHEPPERSON, G.; WALTHAM,R. Forage conservation and feeding. Ipswich: Farming Press, 1978. $340 \mathrm{p}$.

REES, D.V.H.. A discussion of sources of dry matter loss during the process of haymaking. Journal of Agricultural Engeneering Research, v.27, n.6, p. 469-479, 1982. 
ROTZ, C.A.; ABRAMS, S.M. Losses and quality changes during alfalfa hay harverst and storage. Transactions of the ASAE, v.31, n.2, p. 350-355, 1988.

ROTZ, C.A., SPROTT, D.J. Drying rates, losses and fuel requirements for mowing and conditioning alfalfa. Transactions of the ASAE, v. 27, n.3, p. 715-720, 1984.

ROTZ, C.A.; SPROTT, D.J.; THOMAS, J.W. Interaction of mechanical and chemical conditioning of alfalfa. Transactions of the ASAE, v. 27, n. 4, p. 1009-1014, 1984.

RUSSEL, R.S. Plant root systems: their function and interaction with the soil. In: SYMPOSIUM ON THE SOIL/ROOT SYSTEM,1., Londrina, 1980. Proceedings. Londrina : Instituto Agronômico de Pesquisas do Paraná, 1980. p.4-11.

SÁ, J.C.; PETRERE C. Princípios e estratégia de correção do solo e adubação de manutenção. Suplemento Jornal da Dirat, n. 84, p. 2-16, 1991.

SAIBRO, J.C. Produção de alfafa no Rio Grande do Sul. In: SIMPÓSIO SOBRE MANEJO DA PASTAGEM, 7., Piracicaba, 1984. Anais. Piracicaba: FEALQ, 1984. p. $34-40$.

SCALES, C.H.; MOSS, R.A.; QUIN, B.F. Nutritive value of round hay bales. New Zealand Journal of Agricultural Research, v. 137, p. 52-53, 1978.

SIMPSON, B. Effect of crushing on the respiratory drift of pasture plants during drying. Journal of the Science of Food and Agriculture, v. 12, p. 706-711, 1961.

TAYLOR, J.C.; RUDMAN, J.E. Forages: the cutting action in a flail-type mower. In: INTERNATIONAL GRASSLAND CONGRESS, 9., São Paulo, 1965, Proceedings. São Paulo: Secretaria da Agricultura de São Paulo, 1966. p. 16391644. 
THOMAS, J.W.; JOHNSON, T.R.; WIEGHART, M.A. et al. Hastening hay drying. In: INTERNATIONAL GRASSLAND AGRICULTURE CONGRESS, 14. Lexington, 1981. Lexington: American Forage and Grassland Council, 1981.p. 645-648.

TULLBERG, J.N. Laboratory and field studies of the effect of chemical treatments on the drying characteristics of lucerne, and the influence of steam/leaf moisture transfer. Thesis (Phd). Queensland. 1975, $138 \mathrm{p}$.

TURNER, N.C. Speeding the drying of alfalfa hay with fusicoccin. Agronomy Journal. v.62, p. 538-541, 1970.

VAN SOEST, P.J. Development of a comprehensive system of feed analysis its application to forages. Journal of Animal Science, v.26, p. 119-128, 1967.

VILLA NOVA, N.A.; BACCHI, O.S.; REICHARD, T.K. Potencial da água no sistema solo-planta estimado através da fase de vapor. Scientia Agricola, v. 53, n.1, p.194198 , jan/abr. 1996.

WILKINSON, J.M. Losses in the conservation and utilization of grass and forage crop. Animal Applied Biology, v.98, p. 365-375, 1981.

WILMAN, D.; OWEN, I.G. Effects of stage of maturity, nitrogen application and swath tickness on the field drying of herbage to the hay stage. Journal of Agricultural Science, v.99, p.577-586, 1982.

WOLF, O.D.; CARSON, E.W. Respiration durong drying of alfalfa herbage. Crop Science, v. 13, p.660-662, 1973. 
APENNDICE 
TABELA 14: COEFICIENTES DE CORRELAÇÃO ENTRE OS PRINCÍPIOS NUTRITIVOS BRUTOS PROPRIEDADE 1 - PERIODO 1

\begin{tabular}{|c|c|c|c|c|c|c|c|c|}
\hline & MS & RHF & PB & FB & $\mathrm{EE}$ & $\mathrm{MM}$ & ENN & NDT \\
\hline MS & - & $\begin{array}{l}0,52478 \\
0,0175\end{array}$ & $\begin{array}{l}-0,62535 \\
0,0032\end{array}$ & $\begin{array}{l}-0,07912 \\
0,7402\end{array}$ & $\begin{array}{l}0,40965 \\
0,07061\end{array}$ & $\begin{array}{l}-0,27161 \\
0,2467\end{array}$ & $\begin{array}{l}0,36967 \\
0,1087\end{array}$ & $\begin{array}{l}0,29454 \\
0,2070\end{array}$ \\
\hline RHF & - & - & $\begin{array}{l}-0,70310 \\
0,0005\end{array}$ & $\begin{array}{l}-0,38020 \\
0,0901\end{array}$ & $\begin{array}{l}0,66770 \\
0,0015\end{array}$ & $\begin{array}{l}-0,188 \\
0,4262\end{array}$ & $\begin{array}{l}0,50181 \\
0,0201\end{array}$ & $\begin{array}{l}0,4549 \\
0,0438\end{array}$ \\
\hline PB & - & - & - & - & $\begin{array}{l}0,2208 \\
0,34951\end{array}$ & $\begin{array}{l}-0,6838 \\
0,7745\end{array}$ & $\begin{array}{l}-0,69256 \\
0,0007\end{array}$ & $\begin{array}{l}-0,41270 \\
0,07056\end{array}$ \\
\hline FB & - & - & - & - & $\begin{array}{l}0,22080 \\
0,3495\end{array}$ & $\begin{array}{l}-0,68388 \\
0,77453\end{array}$ & $\begin{array}{l}-0,69261 \\
0,0007\end{array}$ & $\begin{array}{l}-0,41271 \\
0,07053\end{array}$ \\
\hline $\mathrm{EE}$ & - & - & - & - & - & $\begin{array}{l}0,19995 \\
0,39801\end{array}$ & $\begin{array}{l}0,25740 \\
0,27332\end{array}$ & $\begin{array}{l}0,67632 \\
0,0001\end{array}$ \\
\hline MM & - & - & - & - & - & - & $\begin{array}{l}0,58150 \\
0,0072\end{array}$ & $\begin{array}{l}-0,76534 \\
0,0001\end{array}$ \\
\hline ENN & - & - & - & - & - & - & - & $\begin{array}{l}0,68115 \\
0,00091\end{array}$ \\
\hline
\end{tabular}

TABELA 15: COEFICIENTES DE CORRELAÇÃO ENTRE OS PRINCÍPIOS NUTRITIVOS BRUTOS PROPRIEDADE 1- PERÍODO 2

\begin{tabular}{|c|c|c|c|c|c|c|c|c|}
\hline & MS & RHF & PB & FB & $\mathrm{EE}$ & $\mathrm{MM}$ & ENN & NDT \\
\hline $\mathrm{MS}$ & - & $\begin{array}{l}0,62564 \\
0,0032\end{array}$ & $\begin{array}{l}-0,70094 \\
0,0006\end{array}$ & $\begin{array}{l}0,91048 \\
0,0001\end{array}$ & $\begin{array}{l}-0,64212 \\
0,0023\end{array}$ & $\begin{array}{l}0,3202 \\
0,1687\end{array}$ & $\begin{array}{l}-0,71467 \\
0,0004\end{array}$ & $\begin{array}{l}-0,90051 \\
0,0001\end{array}$ \\
\hline RHF & - & - & $\begin{array}{l}-0,60357 \\
0,0048\end{array}$ & $\begin{array}{l}0,51084 \\
0,0213\end{array}$ & $\begin{array}{l}-0,27207 \\
0,2459\end{array}$ & $\begin{array}{l}0,13155 \\
0,5804\end{array}$ & $\begin{array}{l}-0,29889 \\
0,2005\end{array}$ & $\begin{array}{l}0,72637 \\
0,0003\end{array}$ \\
\hline PB & - & - & - & $\begin{array}{l}-0,63997 \\
0,0024\end{array}$ & $\begin{array}{l}0,54192 \\
0,0144\end{array}$ & $\begin{array}{l}-0,01863 \\
0,9379\end{array}$ & $\begin{array}{l}0,2005 \\
0,20918\end{array}$ & $\begin{array}{l}0,72637 \\
0,0003\end{array}$ \\
\hline FB & - & - & - & - & $\begin{array}{l}-0,53770 \\
0,0144\end{array}$ & $\begin{array}{l}-0,41231 \\
0,0708\end{array}$ & $\begin{array}{l}-0,87709 \\
0,0001\end{array}$ & $\begin{array}{l}-0,93162 \\
0,0001\end{array}$ \\
\hline $\mathrm{EE}$ & - & - & - & - & - & $\begin{array}{l}-0,4357 \\
0,0446\end{array}$ & $\begin{array}{l}0,34021 \\
0,1422\end{array}$ & $\begin{array}{l}0,75760 \\
0,0001\end{array}$ \\
\hline $\mathrm{MM}$ & - & - & - & - & - & - & $\begin{array}{l}-0,60918 \\
0,0044\end{array}$ & $\begin{array}{l}-0,56096 \\
0,0101\end{array}$ \\
\hline ENN & - & - & - & - & - & - & - & $\begin{array}{l}0,75760 \\
0,0001\end{array}$ \\
\hline
\end{tabular}


TABELA 16: COEFICIENTES DE CORRELAÇÃO ENTRE OS PRINCÍPIOS NUTRITIVOS BRUTOS PROPRIEDADE 2- PERIODO 1

\begin{tabular}{|c|c|c|c|c|c|c|c|c|}
\hline & MS & RHF & PB & FB & $\mathrm{EE}$ & MM & ENN & NDT \\
\hline $\mathrm{MS}$ & - & $\begin{array}{l}0,75348 \\
0,0001\end{array}$ & $\begin{array}{l}-0,76431 \\
0,0001\end{array}$ & $\begin{array}{l}0,75273 \\
0,0001\end{array}$ & $\begin{array}{l}-0,12488 \\
0,5999\end{array}$ & $\begin{array}{l}-0,24129 \\
0,3054\end{array}$ & $\begin{array}{l}0,75611 \\
0,0001\end{array}$ & $\begin{array}{l}-0,40597 \\
0,0757\end{array}$ \\
\hline RHF & - & - & $\begin{array}{l}-0,76374 \\
0,0001\end{array}$ & $\begin{array}{l}-0,22499 \\
0,3413\end{array}$ & $\begin{array}{l}-0,10986 \\
0,6448\end{array}$ & $\begin{array}{l}0,03669 \\
0,8780\end{array}$ & $\begin{array}{l}0,60301 \\
0,0049\end{array}$ & $\begin{array}{l}-0,44404 \\
0,0498\end{array}$ \\
\hline PB & - & - & - & $\begin{array}{l}0,16070 \\
0,4985\end{array}$ & $\begin{array}{l}0,2870 \\
0,2198\end{array}$ & $\begin{array}{l}0,36335 \\
0,1153\end{array}$ & $\begin{array}{l}-0,81115 \\
0,0001\end{array}$ & $\begin{array}{l}0,49418 \\
0,0268\end{array}$ \\
\hline FB & - & - & - & - & $\begin{array}{l}0,27459 \\
0,2414\end{array}$ & $\begin{array}{l}-0,03956 \\
0,86850\end{array}$ & $\begin{array}{l}-0,64782 \\
0,0020\end{array}$ & $\begin{array}{l}-0,37738 \\
0,10090\end{array}$ \\
\hline $\mathrm{EE}$ & - & - & - & - & - & $\begin{array}{l}-0,44210 \\
0,0510\end{array}$ & $\begin{array}{l}0,2876 \\
0,23241\end{array}$ & $\begin{array}{l}-0,37738 \\
0,1009\end{array}$ \\
\hline MM & - & - & - & - & - & - & $\begin{array}{l}-0,47146 \\
0,03591\end{array}$ & $\begin{array}{l}-0,32260 \\
0,1654\end{array}$ \\
\hline ENN & - & - & - & - & - & - & - & $\begin{array}{l}-0,4593 \\
0,8475\end{array}$ \\
\hline
\end{tabular}

TABELA 17: COEFICIENTES DE CORRELAÇÃO ENTRE OS PRINCÍPIOS NUTRITIVOS BRUTOS PROPRIEDADE 2- PERÍODO 2:

\begin{tabular}{|c|c|c|c|c|c|c|c|c|}
\hline & MS & RHF & PB & FB & $\mathrm{EE}$ & MM & ENN & NDT \\
\hline$\overline{M S}$ & - & $\begin{array}{l}0,63707 \\
0,0025\end{array}$ & $\begin{array}{l}-0,81494 \\
0,0001\end{array}$ & $\begin{array}{l}-0,06770 \\
0,7767\end{array}$ & $\begin{array}{l}-0,25066 \\
0,2864\end{array}$ & $\begin{array}{l}0,13237 \\
0,5780\end{array}$ & $\begin{array}{l}0,50854 \\
0,0220\end{array}$ & $\begin{array}{l}-0,47567 \\
0,3402\end{array}$ \\
\hline RHF & - & - & $\begin{array}{l}-0,50098 \\
0,0844\end{array}$ & $\begin{array}{l}-0,16186 \\
0,4957\end{array}$ & $\begin{array}{l}-0,15241 \\
0,5212\end{array}$ & $\begin{array}{l}-0,07480 \\
0,7540\end{array}$ & $\begin{array}{l}0,43807 \\
0,0534\end{array}$ & $\begin{array}{l}-0,19759 \\
0,5346\end{array}$ \\
\hline PB & - & - & - & $\begin{array}{l}0,00449 \\
0,9850\end{array}$ & $\begin{array}{l}0,32926 \\
0,1563\end{array}$ & $\begin{array}{l}-0,23220 \\
0,3246\end{array}$ & $\begin{array}{l}-0,54720 \\
0,0125\end{array}$ & $\begin{array}{l}0,67524 \\
0,0011\end{array}$ \\
\hline FB & - & - & - & - & $\begin{array}{l}0,21378 \\
0,3654\end{array}$ & $\begin{array}{l}-0,11327 \\
0,6345\end{array}$ & $\begin{array}{l}-0,80889 \\
0,0001\end{array}$ & $\begin{array}{l}-0,59844 \\
0,0053\end{array}$ \\
\hline $\mathrm{EE}$ & - & - & - & - & - & $\begin{array}{l}0,10232 \\
0,6677\end{array}$ & $\begin{array}{l}-0,47052 \\
0,0363\end{array}$ & $\begin{array}{l}0,32855 \\
0,15361\end{array}$ \\
\hline MM & - & - & - & - & - & - & $\begin{array}{l}0,01716 \\
0,9427\end{array}$ & $\begin{array}{l}-0,35586 \\
0,1236\end{array}$ \\
\hline ENN & - & - & - & - & - & - & - & $\begin{array}{l}0,14532 \\
0,5410\end{array}$ \\
\hline
\end{tabular}


TABELA 18: COEFICIENTES DE CORRELAÇÃO ENTRE OS PRINCÍPIOS NUTRITIVOS BRUTOS PROPRIEDADE 3- PERIOODO 1:

\begin{tabular}{|c|c|c|c|c|c|c|c|c|}
\hline & MS & RHF & PB & FB & $\mathrm{EE}$ & $\mathrm{MM}$ & ENN & NDT \\
\hline$\overline{M S}$ & - & $\begin{array}{l}0,42927 \\
0,0586\end{array}$ & $\begin{array}{l}-0,77078 \\
0,0001\end{array}$ & $\begin{array}{l}-0,26845 \\
0,2525\end{array}$ & $\begin{array}{l}0,11974 \\
0,6151\end{array}$ & $\begin{array}{l}-0,25530 \\
0,2773\end{array}$ & $\begin{array}{l}0,59531 \\
0,0056\end{array}$ & $\begin{array}{l}-0,00164 \\
0,9945\end{array}$ \\
\hline RHF & - & - & $\begin{array}{l}-0,69784 \\
0,0020\end{array}$ & $\begin{array}{l}0,34966 \\
0,1397\end{array}$ & $\begin{array}{l}-0,29873 \\
0,2008\end{array}$ & $\begin{array}{l}-0,05707 \\
0,8111\end{array}$ & $\begin{array}{l}0,04150 \\
0,8621\end{array}$ & $\begin{array}{l}-0,62138 \\
0,0035\end{array}$ \\
\hline PB & - & - & - & $\begin{array}{l}0,11684 \\
0,6237\end{array}$ & $\begin{array}{l}-0,05516 \\
0,8173\end{array}$ & $\begin{array}{l}0,22584 \\
0,3384\end{array}$ & $\begin{array}{l}-0,57691 \\
0,0077\end{array}$ & $\begin{array}{l}0,24459 \\
0,2987\end{array}$ \\
\hline FB & - & - & - & - & $\begin{array}{l}-0,28650 \\
0,22071\end{array}$ & $\begin{array}{l}0,12702 \\
0,5936\end{array}$ & $\begin{array}{l}-0,86006 \\
0,0001\end{array}$ & $\begin{array}{l}-0,86434 \\
0,0001\end{array}$ \\
\hline $\mathrm{EE}$ & - & - & - & - & - & $\begin{array}{l}0,15017 \\
0,52741\end{array}$ & $\begin{array}{l}0,16029 \\
0,49961\end{array}$ & $\begin{array}{l}0,44937 \\
0,04681\end{array}$ \\
\hline $\mathrm{MM}$ & - & - & - & - & - & - & $\begin{array}{l}-0,36468 \\
0,1139\end{array}$ & $\begin{array}{l}-0,26709 \\
0,2550\end{array}$ \\
\hline ENN & - & - & - & - & - & - & - & $\begin{array}{l}0,59520 \\
0,0056\end{array}$ \\
\hline
\end{tabular}

TABELA 19: COEFICIENTES DE CORRELAÇÃO ENTRE OS PRINCÍPIOS NUTRITIVOS BRUTOS PROPRIEDADE 3- PERÍODO 2:

\begin{tabular}{|c|c|c|c|c|c|c|c|c|}
\hline & MS & RHF & PB & FB & $\mathrm{EE}$ & MM & ENN & NDT \\
\hline $\mathrm{MS}$ & - & $\begin{array}{l}0,93805 \\
0,0001\end{array}$ & $\begin{array}{l}-0,5238 \\
0,0177\end{array}$ & $\begin{array}{l}0,12970 \\
0,5858\end{array}$ & $\begin{array}{l}-0,28630 \\
0,2210\end{array}$ & $\begin{array}{l}-0,32602 \\
0,1671\end{array}$ & $\begin{array}{l}0,41738 \\
0,06671\end{array}$ & $\begin{array}{l}-0,29980 \\
0,1991\end{array}$ \\
\hline RHF & - & - & $\begin{array}{l}-0,47550 \\
0,0341\end{array}$ & $\begin{array}{l}0,11390 \\
0,6326\end{array}$ & $\begin{array}{l}-0,20745 \\
0,3802\end{array}$ & $\begin{array}{l}-0,37676 \\
0,1015\end{array}$ & $\begin{array}{l}0,39248 \\
0,0870\end{array}$ & $\begin{array}{l}-0,20874 \\
0,3771\end{array}$ \\
\hline PB & - & - & - & $\begin{array}{l}-0,28619 \\
0,2212\end{array}$ & $\begin{array}{l}-0,05772 \\
0,8090\end{array}$ & $\begin{array}{l}-0,00220 \\
0,9926\end{array}$ & $\begin{array}{l}-0,40392 \\
0,0483\end{array}$ & $\begin{array}{l}0,44675 \\
0,0483\end{array}$ \\
\hline FB & - & - & - & - & $\begin{array}{l}-0,01669 \\
0,9443\end{array}$ & $\begin{array}{l}0,08438 \\
0,7236\end{array}$ & $\begin{array}{l}-0,66839 \\
0,0013\end{array}$ & $\begin{array}{l}-0,59849 \\
0,0053\end{array}$ \\
\hline $\mathrm{EE}$ & - & - & - & - & - & $\begin{array}{l}-0,05620 \\
0,8140\end{array}$ & $\begin{array}{l}-0,21260 \\
0,3682\end{array}$ & $\begin{array}{l}0,63805 \\
0,0025\end{array}$ \\
\hline MM & - & - & - & - & - & - & $\begin{array}{l}-0,36628 \\
0,1122\end{array}$ & $\begin{array}{l}-0,44897 \\
0,0471\end{array}$ \\
\hline ENN & - & - & - & - & - & - & - & $\begin{array}{l}0,16574 \\
0,4850\end{array}$ \\
\hline
\end{tabular}


TABELA 20: ANÁLISE VARIÂNCIA -PROPRIEDADE 1:

\begin{tabular}{lllllllll}
\hline & MS & RHF & PB & FB & EE & MM & ENN & NDT \\
\hline & R-0,9929 & R-0,8682 & R-0,7902 & R-0,8373 & R-0,7124 & R-0,7230 & R-0,6930 & R-0,7310 \\
& $\begin{array}{l}\text { C-3,87 } \\
\text { Pr>F }\end{array}$ & C-15,69 & C-4,84 & C-6,77 & C-23,88 & C-5,72 & C-4,91 & C-2,67 \\
\hline P & 0,0001 & 0,0001 & 0,3273 & 0,0114 & 0,2108 & 0,0001 & 0,0072 & 0,2501 \\
P*R & 0,2579 & 0,5671 & 0,8961 & 0,3836 & 0,5986 & 0,6105 & 0,4813 & 0,4872 \\
F & 0,0001 & 0,0001 & 0,001 & 0,0063 & 0,0303 & 0,4463 & 0,2097 & 0,0185 \\
P*F & 0,0001 & 0,0061 & 0,6894 & 0,0001 & 0,0001 & 0,0005 & 0,0002 & 0,0001 \\
\hline
\end{tabular}

TABELA 21: ANÁLISE VARIÂNCIA -PROPRIEDADE 2:

\begin{tabular}{|c|c|c|c|c|c|c|c|c|}
\hline & MS & RHF & PB & FB & $\mathrm{EE}$ & MM & ENN & NDT \\
\hline & R-0,9890 & R-0,7866 & R-0,9380 & R-0,8097 & R- 0,4984 & R-0,5382 & R-0,5699 & $\mathrm{R}-0,5212$ \\
\hline & C- $-5,505$ & C-18,69 & C- 3,22 & C-8,97 & C- 18,26 & C- 8,60 & C- 5,44 & $C-1,50$ \\
\hline & $\operatorname{Pr}>\mathrm{F}$ & $\operatorname{Pr}>F$ & $\mathrm{Pr}>\mathrm{F}$ & $\operatorname{Pr}>F$ & $\operatorname{Pr}>\mathrm{F}$ & $\mathrm{Pr}>\mathrm{F}$ & $\operatorname{Pr}>\mathrm{F}$ & $\operatorname{Pr}>F$ \\
\hline $\mathrm{P}$ & 0,0001 & 0,0024 & 0,1822 & 0,4969 & 0,0358 & 0,0017 & 0,8312 & 0,0282 \\
\hline $\mathrm{P} * \mathrm{R}$ & 0,4142 & 0,8748 & 0,4542 & 0,5426 & 0,2023 & 0,4577 & 0,3274 & 0,7588 \\
\hline F & 0,0001 & 0,0001 & 0,0001 & 0,9663 & 0,2504 & 0,5042 & 0,0022 & 0,0150 \\
\hline $\mathrm{P} * \mathrm{~F}$ & 0,0001 & 0,0004 & 0,0945 & 0,9938 & 0,4554 & 0,2251 & 0,8404 & 0,7402 \\
\hline
\end{tabular}

Onde: $\mathrm{P}=$ período; $\mathrm{F}=$ fase; $\mathrm{P} * \mathrm{R}=$ período*repetição; $\mathrm{P} * \mathrm{~F}=$ período*fase, $\mathrm{R}=\mathrm{R} 2$ $\mathrm{C}=$ coeficiente de variância $\mathrm{MS}=$ matéria seca, $\mathrm{RHF}=$ relação haste/folha, $\mathrm{PB}$-proteína bruta, $\mathrm{FB}=$ fibra bruta, $\mathrm{EE}=$ extrato etéreo, $\mathrm{MM}=$ matéria mineral, $\mathrm{ENN}=$ =xtrativo não nitrogenado, NDT=nutrientes digestiveis totais. 
TABELA 22: ANÁLISE VARIÂNCIA -PROPRIEDADE 3:

\begin{tabular}{|c|c|c|c|c|c|c|c|c|}
\hline & MS & RHF & PB & FB & $\mathrm{EE}$ & MM & ENN & NDT \\
\hline & $\mathrm{R}-0,9854$ & R-0;8943 & R-0,7359 & $\mathrm{R}-0,5537$ & $\mathrm{R}-0,8771$ & R- 0,4839 & $R-0,6526$ & $\mathrm{R}-0,7421$ \\
\hline & $C-7,41$ & C- $14 ; 68$ & C- 8,43 & C- 8,43 & C- 11,00 & C-5,34 & C-4,36 & $C-1,51$ \\
\hline & $\mathrm{Pr}>\mathrm{F}$ & $\operatorname{Pr}>\mathrm{F}$ & $\mathrm{Pr}>\mathrm{F}$ & $\operatorname{Pr}>\mathrm{F}$ & $\operatorname{Pr}>\mathrm{F}$ & $\mathrm{Pr}>\mathrm{F}$ & $\operatorname{Pr}>\mathrm{F}$ & $\operatorname{Pr}>F$ \\
\hline $\mathrm{P}$ & 0,0184 & 0,0049 & 0,0506 & 0,0351 & 0,0001 & 0,9016 & 0,0279 & 0,0010 \\
\hline $\mathrm{P} * \mathrm{R}$ & 0,9092 & 0,3830 & 0,4840 & 0,9834 & 0,0135 & 0,3667 & 0,5342 & 0,9016 \\
\hline $\mathrm{F}$ & 0,0001 & 0,0001 & 0,0001 & 0,0821 & 0,0004 & 0,0219 & 0,0033 & 0,0006 \\
\hline $\mathrm{P}^{*} \mathrm{~F}$ & 0,0001 & 0,0003 & 0,0361 & 0,0197 & 0,0001 & 0,8036 & 0,0271 & 0,0016 \\
\hline
\end{tabular}

Onde: $\mathrm{P}=$ =periodo; $\mathrm{F}=$ fase; $\mathrm{P} * \mathrm{R}=$ período*repetição; $\mathrm{P} * \mathrm{~F}=$ período*fase, $\mathrm{R}=\mathrm{R} 2$ $\mathrm{C}=$ coeficiente de variância $\mathrm{MS}=$ matéria seca, $\mathrm{RHF}=$ relação haste/folha, $\mathrm{PB}=$ proteína bruta, $\mathrm{FB}=$ fibra bruta, $\mathrm{EE}=$ extrato etéreo, $\mathrm{MM}=$ matéria mineral, $\mathrm{ENN}=$ extrativo não nitrogenado, NDT=nutrientes digestíveis totais. 
TABELA 23: ASPECTOS CLIMATOLÓGICOS DA PROPRIEDADE 1-PERÍODO 1:

\begin{tabular}{lllllllll}
\hline FASES & DATA & TMAX & TMIN & TMED & UR\% & VENTO RAD & INSOL \\
\hline 1 & $28 / 06 / 94$ & 23.4 & 2.5 & 12.5 & 53.2 & 75 & 339 & 9.5 \\
\hline 2 & $28 / 06 / 94$ & 23.4 & 2.5 & 12.5 & 53.2 & 75 & 339 & 9.5 \\
\hline 3 & $29 / 06 / 94$ & 24.3 & 7.8 & 14.7 & 55.7 & 328 & 328 & 10 \\
\hline 4 & $30 / 06 / 94$ & 27.4 & 9.8 & 19.1 & 62.5 & 313 & 298 & 9.6 \\
\hline 5 & $13 / 07 / 94$ & 25.3 & 10.2 & 17.1 & 61.1 & 364 & 320 & 9.8
\end{tabular}

TABELA 24: ASPECTOS CLIMATOLÓGICOS DA PROPRIEDADE 1-PERÍODO 2:

\begin{tabular}{lcccccccc}
\hline FASES & DATA & TMAX & TMFN & TMED & UR\% & VENTO RAD & INSOL \\
\hline 1 & $17 / 08 / 94$ & 25.1 & 13.0 & 17.2 & 65.2 & 263 & 362 & 9.8 \\
\hline 2 & $17 / 08 / 94$ & 25.1 & 13.0 & 17.2 & 65.2 & 263 & 362 & 9.8 \\
\hline 3 & $18 / 08 / 94$ & 27.2 & 11.5 & 19.4 & 56.1 & 566 & 369 & 9.9 \\
\hline 4 & $19 / 08 / 94$ & 29.9 & 13.7 & 20.4 & 52.1 & 362 & 350 & 9.5 \\
\hline 5 & $24 / 08 / 94$ & 31.6 & 12.2 & 22.3 & 37.6 & 159 & 285 & 10.4
\end{tabular}

Onde $\quad \mathrm{TMAX}=$ Temperatura máxima em ${ }^{\circ} \mathrm{C} ; \mathrm{TMIN}=$ temperatura mínima $\mathrm{em}{ }^{\circ} \mathrm{C}$; $\mathrm{TMED}=$ temperatura média ${ }^{\circ} \mathrm{C}, \mathrm{UR} \%=$ umidade relativa do ar $(\%) ; \mathrm{VENTO}=$ vento em $\mathrm{Km} /$ acumulados/dia; $\mathrm{RAD}=$ radiação em calorias por $\mathrm{cm}^{2} / \mathrm{dia} ; \mathrm{INSOL}=$ insolação em horas/sol/dia. 
TABELA 25 : ATIVIDADE DE ÁGUA NO AR EM FUNÇÃO DA TEMPERATURA E UMIDADE RELATIVA DO AR - PROPRIEDADE 1

\begin{tabular}{lcclccc}
\hline FASES & \multicolumn{2}{l}{ PERIODO 1} \\
\hline & $\mathrm{T}^{\circ} \mathrm{C}$ & UR $\%$ & $\Psi$ & $\mathrm{T}^{\circ} \mathrm{C}$ & UR $\%$ & $\Psi$ \\
\hline 1 & 12.5 & 53.2 & -820 & 17.2 & 65.2 & -565 \\
\hline 2 & 12.5 & 53.2 & -820 & 17.2 & 65.2 & -565 \\
\hline 3 & 14.7 & 55.7 & -729 & 19.4 & 56.1 & -769 \\
\hline 4 & 19.1 & 62.5 & -625 & 20.4 & 52.1 & -870 \\
\hline 5 & 17.1 & 62.1 & -629 & 22.3 & 50.1 & -929 \\
\hline
\end{tabular}

ONDE: $\Psi=$ atividade de água de ar $; \Psi=4.55 \mathrm{~T} \operatorname{Ln} \mathrm{UR} / 100 ; \mathrm{T}=$ temperatura $\mathrm{em}^{\circ} \mathrm{K}$; UR \%-umidade relativa do ar .

* Cálculo de $\Psi=4.55$ T Ln UR/100- fonte: VILLA NOVA et al (1996)

TABELA 26. ASPECTOS CLIMATOLÓGICOS PROPRIEDADE 2-PERIODO1

\begin{tabular}{lllllllll}
\hline FASES & DATA & TMAX & TMIN & TMED & UR\% & VENTO RAD & INSOL \\
\hline 1 & $27 / 6 / 94$ & 20.6 & 0.4 & 10.2 & 66.2 & 90 & 341 & 9.6 \\
\hline 2 & $27 / 6 / 94$ & 20.6 & 0.4 & 10.2 & 66.2 & 90 & 341 & 9.6 \\
\hline 3 & $28 / 6 / 94$ & 23.4 & 2.5 & 12.5 & 53.2 & 75 & 339 & 9.5 \\
\hline 4 & $29 / 6 / 94$ & 24.3 & 7.8 & 14.7 & 55.7 & 328 & 328 & 10 \\
\hline 5 & $13 / 7 / 94$ & 25.3 & 10.2 & 17.1 & 61.1 & 364 & 320 & 9.8 \\
\hline
\end{tabular}

ONDE: Tmax $=$ temperatura máxima, Tmin $=$ temperatura mínima, tmed $=$ temperatura média ( expressas em ${ }^{\circ} \mathrm{C}$ ); UR $\%=$ umidade relativa- $\%$; vento $-\mathrm{km}$ acumulados/dia; $\mathrm{RAD}=$ radiação-calorias/cm2/dia;INSOL = insolação- horas/sol/dia. 
TABELA 27 -ASPECTOS CLIMATOLÓGICOS PROPRIEDADE 2-PERÍODO 2

\begin{tabular}{lllllllll}
\hline FASES & DATA & TMAX & TMIN & TMED & UR \% & VENTO RAD & INSOL \\
\hline 1 & $15 / 8 / 94$ & 20.97 & 13.8 & 20.5 & 51.7 & 181 & 342 & 9.8 \\
\hline 2 & $15 / 8 / 94$ & 20.97 & 13.8 & 20.5 & 51.7 & 181 & 342 & 9.8 \\
\hline 3 & $16 / 8 / 94$ & 30.5 & 11.8 & 21.2 & 47.3 & 104 & 342 & 10 \\
\hline 4 & $17 / 8 / 94$ & 25.1 & 13.0 & 17.2 & 65.2 & 263 & 362 & 9.8 \\
\hline 5 & $22 / 8 / 94$ & 31.6 & 12.2 & 22.3 & 57.3 & 159 & 285 & 10.4
\end{tabular}

ONDE: $T \max =$ temperatura máxima, $\mathrm{T} \min =$ temperatura mínima, tmed $=$ temperatura média ( expressas em ${ }^{\circ} \mathrm{C}$ ); UR $\%=$ umidade relativa- \%; vento $-\mathrm{km}$ acumulados/dia; $\mathrm{RAD}=$ radiação-calorias $/ \mathrm{cm} 2 /$ dia; $\mathrm{INSOL}=$ insolação- horas $/ \mathrm{sol} / \mathrm{dia}$.

TABELA 28: ATIVIDADE DE AGUA DO AR EM FUNÇÃO DA TEMPERATURA E UMIDADE RELATIVA DO AR- PROPRIEDADE 2

\begin{tabular}{lcccccc}
\hline FASES & \multicolumn{2}{l}{ PERIODO 1 } & \multicolumn{5}{l}{ PERIODO 2 } \\
\hline & $\mathrm{T}^{\circ} \mathrm{C}$ & UR $\%$ & $\Psi$ & $\mathrm{T}^{\circ} \mathrm{C}$ & UR $\%$ & $\Psi$ \\
\hline 1 & 10.2 & 66.2 & -531 & 20.5 & 51.7 & -881 \\
\hline 2 & 10.2 & 66.2 & -531 & 20.5 & 51.7 & -881 \\
\hline 3 & 12.5 & 53.2 & -820 & 21.2 & 57.3 & -745 \\
\hline 4 & 14.7 & 55.7 & -765 & 17.2 & 65.2 & -564 \\
\hline 5 & 17.1 & 61.1 & -650 & 22.3 & 57.6 & -741 \\
\hline
\end{tabular}

$\Psi=$ atividade de água no ar $; \mathrm{T}^{\circ} \mathrm{C}=$ temperatura; $\mathrm{UR} \%=$ umidade relativa do ar $\Psi=4.55 \mathrm{~T}^{\circ} \mathrm{K} \mathrm{Ln} \mathrm{UR/100}$; onde $\mathrm{T}^{\circ} \mathrm{K}=$ temperatura em graus kelvin; $\mathrm{Ln} \mathrm{UR}=$ logaritmo da umidade relativa do ar

* Cálculo de $\Psi=4.55$ T Ln UR/100- fonte: VILLA NOVA et al (1996) 
TABELA 29: ASPECTOS CLIMATOLÓGICOS - PROPRIEDADE 3 - PERÍODO 1:

\begin{tabular}{lcccccccc}
\hline FASES & DATA & TMAX & TMIN & TMED & UR\% & VENTO RAD & INSOL \\
\hline 1 & $11 / 7 / 94$ & 19.9 & 6.9 & 13.0 & 64.2 & 477 & 340 & 10.1 \\
\hline 2 & $11 / 7 / 94$ & 19.9 & 6.9 & 13.0 & 64.2 & 477 & 340 & 10.1 \\
\hline 3 & $12 / 7 / 94$ & 22.8 & 10.7 & 15.5 & 58.7 & 597 & 320 & 10.0 \\
\hline 4 & $13 / 7 / 94$ & 25.3 & 10.2 & 17.1 & 61.1 & 364 & 320 & 9.8 \\
\hline 5 & $18 / 7 / 94$ & 20.9 & 11.2 & 20.1 & 50.5 & 110 & 320 & 9.9
\end{tabular}

TABELA 26: ASPECTOS CLIMÁTICOS -PROPRIEDADE 3-PERÍODO 2

\begin{tabular}{lcccccccc}
\hline FASES & DATA & TMAX & TMIN & TMED & UR\% & VENTO RAD & INSOL \\
\hline 1 & $16 / 8 / 94$ & 30.5 & 11.8 & 21.2 & 47.3 & 104 & 285 & 10 \\
\hline 2 & $16 / 8 / 94$ & 30.5 & 11.8 & 21.2 & 57.3 & 104 & 369 & 10 \\
\hline 3 & $17 / 8 / 94$ & 25.1 & 13.0 & 17.2 & 65.2 & 263 & 362 & 9.8 \\
\hline 4 & $18 / 8 / 94$ & 27.2 & 11.5 & 19.4 & 56.1 & 566 & 369 & 9.9 \\
\hline 5 & $22 / 8 / 94$ & 31.6 & 12.2 & 22.3 & 57.6 & 159 & 285 & 10.4
\end{tabular}

ONDE: Tmax $=$ temperatura máxima, Tmin $=$ temperatura minima, tmed $=$ temperatura média ( expressas em ${ }^{\circ} \mathrm{C}$ ); UR $\%=$ umidade relativa- $\%$; vento $-\mathrm{km}$ acumulados/dia; $\mathrm{RAD}=$ radiação-calorias $/ \mathrm{cm} 2 /$ dia; $\mathrm{INSOL}=$ insolação- horas $/ \mathrm{sol} /$ dia. 
TABELA 31: ATIVIDADE DE ÁGUA DO AR EM FUNÇÃO DA TEMPERATURA E DA UMIDADE RELATIVA DO AR- PROPRIEDADE 3 :

\begin{tabular}{lcccccc}
\hline FASES & \multicolumn{2}{l}{ PERIODO 1 } & \multicolumn{4}{l}{ PERÍODO 2 } \\
\hline & $\mathrm{T}^{\circ} \mathrm{C}$ & UR $\%$ & $\Psi$ & $\mathrm{T}{ }^{\circ} \mathrm{C}$ & $\mathrm{UR} \%$ & $\Psi$ \\
\hline 1 & 13.0 & 64.2 & -577 & 21.2 & 57.3 & -745 \\
\hline 2 & 13.0 & 64.2 & -577 & 21.2 & 57.3 & -745 \\
\hline 3 & 15.5 & 58.7 & -699 & 17.2 & 65.2 & -572 \\
\hline 4 & 17.1 & 61.1 & -670 & 19.4 & 56.1 & -769 \\
\hline 5 & 20.1 & 50.5 & -911 & 22.3 & 57.6 & -741 \\
\hline
\end{tabular}

$\Psi=$ atividade de água no ar $; \mathrm{T}^{\circ} \mathrm{C}=$ temperatura; $\mathrm{UR} \%=$ umidade relativa do ar $\Psi=4.55 \mathrm{~T}^{\circ} \mathrm{K}$ Ln UR $/ 100$; onde $\mathrm{T}^{\circ} \mathrm{K}=$ temperatura em graus kelvin; $\mathrm{Ln} \mathrm{UR}=$ logaritmo da umidade relativa do ar

* Cálculo de $\Psi=4.55$ T Ln UR/100- fonte: VILLA NOVA et al (1996) 